\begin{tabular}{|c|c|c|c|c|c|c|}
\hline \multirow{4}{*}{ Impact Factor: } & ISRA (India) & $=3.117$ & SIS (USA) & $=0.912$ & ICV (Poland) & $=6.630$ \\
\hline & ISI (Dubai, UAE & $=0.829$ & РИНЦ (Russia) & $=0.156$ & PIF (India) & $=1.940$ \\
\hline & GIF (Australia) & $=0.564$ & ESJI (KZ) & $=8.716$ & IBI (India) & $=4.260$ \\
\hline & JIF & $=1.500$ & SJIF (Morocco) & $=5.667$ & OAJI (USA) & $=0.350$ \\
\hline
\end{tabular}

\begin{tabular}{|c|c|}
\hline $\begin{array}{l}\text { SOI: } \underline{1.1 / \mathrm{T}} \\
\text { International Sc } \\
\text { Theoretical } \boldsymbol{\&}\end{array}$ & $\begin{array}{l}\text { AS DOI: } 10.15863 / \text { TAS } \\
\text { ientific Journal }\end{array}$ \\
\hline p-ISSN: 2308-4944 (print) & e-ISSN: 2409-0085 (online) \\
\hline Year: 2019 Issue: 03 & Volume: 71 \\
\hline Published: 05.03.2019 & http://T-Science.org \\
\hline
\end{tabular}

UDC 335. 47 519. 74.

SECTION: TECHNICAL SCIENCES
QR - Issue

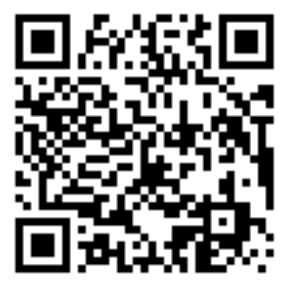

Artur Alexandrovich Blagorodov bachelor,

Department of "Design, technology, and design" Institute of service sector and entrepreneurship (branch) of DSTU in Shakhty, Rostov region bordux1995@icloud.com

\section{Dmitry Olegovich Bordukh} bachelor, Department of "Design, technology, and design" Institute of service sector and entrepreneurship (branch) of DSTU in Shakhty, Rostov region bordux1995@icloud.com

\section{Angelina Vladimirovna Kopylova} bachelor,

Department of "Design, technology, and design" Institute of service sector and entrepreneurship (branch) of DSTU in

Shakhty, Rostov region prohorov@sssu.ru

Daria Sergeevna Smolina bachelor,

Department of "Design, technology, and design" Institute of service sector and entrepreneurship (branch) of DSTU in

Shakhty, Rostov region prohorov@sssu.ru

Vladimir Timofeevich Prokhorov Doctor of technical sciences, professor, the department "Designing, technology and design", ISOP

(f) DGTU, Shakhty prohorov@sssu.ru

Yuri Dmitrievich Mishin candidate of philosophy, Professor, Department of Philosophy and Culturology "Siberian state University of railway communication" Novosibirsk vinichenkoan@stu.ru

\title{
METHODOLOGICAL BASES OF QUALITY MANAGEMENT OF DIGITAL PRODUCTION OF DEFECT-FREE AND IMPORT- SUBSTITUTING TRUE FOR USERS OF THE SFD AND SKFO (1 MESSAGE)
}

Abstract: In report 1, the authors analyze the possibilities of policy and objectives of the company in the field of quality within the QMS in order to fight for defect-free production, reduction of marriage and guarantees consumers high quality of manufactured products. The use of Pareto charts allowed us to visualize the efficiency 


\begin{tabular}{|c|c|c|c|c|c|c|}
\hline \multirow{4}{*}{ Impact Factor: } & ISRA (India) & $=3.117$ & SIS (USA) & $=0.912$ & ICV (Poland) & $=6.630$ \\
\hline & ISI (Dubai, UAE & $=0.829$ & РИНЦ (Russia & $=0.156$ & PIF (India) & $=1.940$ \\
\hline & GIF (Australia) & $=0.564$ & ESJI (KZ) & $=8.716$ & IBI (India) & $=4.260$ \\
\hline & JIF & $=1.500$ & SJIF (Morocco & $=5.667$ & OAJI (USA) & $=0.350$ \\
\hline
\end{tabular}

and effectiveness developed by the authors of the policies and objectives in the field of quality within the QMS to ensure defect-free production with a substantial decrease in the production of defective products. The need to improve the quality management system in the light industry is due to the following important reasons. First, it is increasing the confidence of potential consumers in the products that the company produces. Secondly, it is an opportunity to significantly strengthen its position in existing markets, as well as significantly expand its sphere of influence by entering new domestic and foreign markets. And thirdly - it is a significant increase in productivity of any industrial enterprise which is supposed to introduce QMS using participatory management.

Key words: QMS, certification, import substitution, demanded, conformity assessment, standardization, audit, demand, defective products, Pareto chart, quality policy and objectives, documentation, effectiveness, efficiency, responsibility.

Language: Russian

Citation: Blagorodov, A. A., Bordukh, D. O., Kopylova, A. V., Smolina, D. S., Prokhorov, V. T., \& Mishin, Y. D. (2019). Methodological bases of quality management of digital production of defect-free and importsubstituting true for users of the SFD and SKFO (1 MESSAGE). ISJ Theoretical \& Applied Science, 03 (71), 2257.

\section{Soi: http://s-o-i.org/1.1/TAS-03-71-6 Doi: rossef https://dx.doi.org/10.15863/TAS.2019.03.71.6 \\ МЕТОДОЛОГИЧЕСКИЕ ОСНОВЫ УПРАВЛЕНИЯ КАЧЕСТВОМ ЦИФРОВОГО ПРОИЗВОДСТВА БЕЗДЕФЕКТНОЙ И ИМПОРТОЗАМЕЩАЕМОЙ ПРОДУЦИИ ДЛЯ ПОТРЕБИТЕЛЕЙ ЮФО И СКФО (СООБЩЕНИЕ 1)}

Аннотация: в сообщении 1 авторы анализируют возможности политики и цели предприятия в области качества в рамках СМК для того, чтобы бороться за бездефектное производство, снижение брака и гарантирует потребителям высокое качество изготавливаемой продукции. Использование диаграммы Парето позволили наглядно представить эффективность и результативность разработанной авторами политики и челей в области качества в рамках СМК для обеспечения бездефектного производства с существенным снижением выпуска бракованной продукиии. Необходимость совершенствования системы менеджмента качества на предприятиях легкой промышленности обусловлено следующими важными причинами. Во-первых, это повышение доверия потенцииальных потребителей к продукции, которую выпускает данное предприятие. Во-вторых, это возможность значительно укрепить свое положение на уже существующих рынках, а также значительно расширить сферы влияния путем выхода на новые отечественные и зарубежные рынки. И в-третьих это значительное повышение производительности труда любого промышленного предприятия на котором предполагается внедрение СМК с использованием партисипативного управления.

Ключевые слова: СМК, сертификация, импортозамещение, востребованное, подтверждение соответствия, стандартизация, аудит, спрос, бракованная продукция, диаграмма Парето, политика и цели качества, документация, результативность, эффективность, ответственность.

\section{Введение}

Платежеспособный спрос подавляющего большинства граждан России не позволяет им ориентироваться на качество товара. Сдвиг в сторону интереса к качеству товара должен пройти обязательный этап расширения ассортимента доступного товара для массового покупателя, a данный этап не пройден россиянами, что в прочем не означает деактуализации качества товара.

Интегрируя сказанное, приведем формулу (1.1), позволяющую раскрыть слагаемые качества товара, то есть продукта, произведенного человеком для удовлетворения определенных потребностей. Под нее можно подвести и явления естественного происхождения, включенные в рыночные отношения: чистый воздух, минеральные источники, лечебные грязи, глины, теплое море и т.п., а также то, чье производство рассчитано не на реализацию, рассматривая данные случаи, как упрощенный вариант:

$$
\mathbf{K}_{\mathrm{T}}=\underbrace{\sum \text { ec }+д+\overbrace{\Pi}^{\mathbf{C}}+\mathbf{P}}_{\text {объективная составная }}
$$

где $K_{T}-$ качество товара;

$\sum e c-$ сумма естественных свойств материала;

Д - деятельность, превращаются естественные предпосылки в товар;

$C_{\Pi}$ - сознание покупателя;

$P$ - рекламное сопровождение.

Графический эквивалент формулы (1.1) представлен на рисунке. 1 


\begin{tabular}{|c|c|c|c|c|c|c|}
\hline \multirow{4}{*}{ Impact Factor: } & ISRA (India) & $=3.117$ & SIS (USA) & $=0.912$ & ICV (Poland) & $=6.630$ \\
\hline & ISI (Dubai, UAE & $=0.829$ & РИНЦ (Russia) & $=0.156$ & PIF (India) & $=1.940$ \\
\hline & GIF (Australia) & $=0.564$ & ESJI (KZ) & $=8.716$ & IBI (India) & $=4.260$ \\
\hline & JIF & $=1.500$ & SJIF (Morocco) & $=5.667$ & OAJI (USA) & $=0.350$ \\
\hline
\end{tabular}

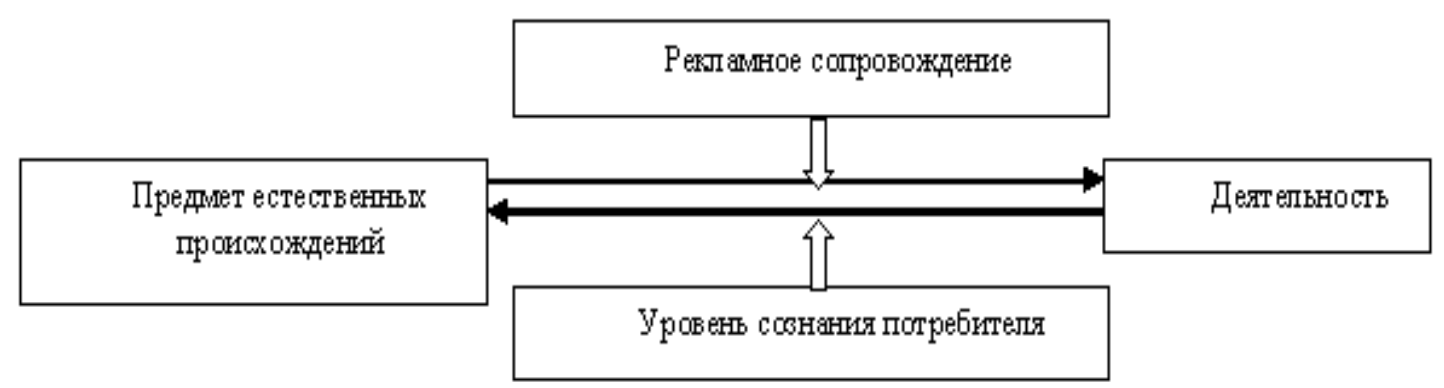

Рис. 1. Графический эквивалент приведенной выше формулы (1.1).

Эта формула описывает и качество интеллектуального продукта. Для чего надо расширить толкование понятия «естественные свойства» за счет включения в его содержание интеллектуальных и психофизиологических предпосылок творческой деятельности. Экономическое понимание качества, на фундаменте которого непосредственно разрабатывались все известные концепции управления качеством производства, эволюционировало согласно диалектическим законам, притом, что сами экономисты далеко не всегда осознавали диалектику процесса.[1-3]

Экономический аспект

Развитие экономического осознания качества осуществлялось «под действием противоречий между внутренними и внешними целями производителя - обеспечением качества выпускаемой продукции и соответственно укреплением положения производителя на рынке (внешняя цель), а также повышением эффективности производства, то есть увеличением прибыли компаний (внутренняя цель). На каждой стадии производства, рынка и общества это противоречие имело свою специфику и по-разному разрешалось».

Б.С. Алешин с соавторами выделяет четыре фазы в становлении современного философскоэкономического толкования качества: «фазу отбраковки», «фазу управления качеством», «фазу постоянного повышения качества» и «программу менеджмента качества».

История экономического управления качеством своим началом уходит в эпоху цехового производства. В средневековых городах обязательно создавались цеховые организации, одной из важнейших функций которых была сертификация мастеров. Чтобы стать признанным мастером, требовалось пройти серьезную проверку своих изделий на качество. Все изделия цеховых мастеров имели авторское «клеймо» и были уникальными в своем роде. Управление качеством упрощалось самим производством, его мануфактурным характером, не позволявшим производству развернуться в масштабе. Никаких согласованных стандартов качества в то время, разумеется, не существовало по причине сложности сравнивать строго индивидуальные продукты мастеров и тем более пытаться разработать некую модель для подражания. Уникальность работы мастера исключала подражательство чему-либо в принципе.

Лишь много времени спустя, на оружейных заводах С. Кольта появилась стандартизация качества изделий. На такое необычное решение подтолкнул тот факт, что в условиях массового производства конечный продукт стали собирать не из специально сделанных и подогнанных под него деталей, а из случайно выбранных из соответствующей партии. Производство впервые оснастили специальными калибрами, и обученные контролеры проверяли на них детали перед сборкой.

Расцвет идеи стандартизации пришелся на эпоху освоения производства автомобилей в США. Г. Леланд, создатель фирмы «Кадиллак», придумал пару: «проходной» и «непроходной» калибр. Г.Форд, построив сборочный конвейер, пошел дальше. Он входной контроль комплектующих заменил контролем выходным, благодаря чему на главное производство сборку, доставлялись калиброванные, качественные детали, что заметно повысило производительность труда и существенно улучшило качество конечного продукта. На заводах Форда так же впервые была создана служба технического контроля, независимая от производства.

Ф. Тейлор, единомышленник Г. Форда, трудившийся в творческой связке со своим патроном, проделал серьезную работу по научному осмыслению нововведений в производстве. В итоге ему удалось сформулировать принципы научного менеджмента ориентированного на качество производства: системный подход; кадровый менеджмент; обязательное разделение ответственности между исполнителями и организаторами в достижении качественной и 


\begin{tabular}{|c|c|c|c|c|c|c|}
\hline \multirow{4}{*}{ Impact Factor: } & ISRA (India) & $=3.117$ & SIS (USA) & $=0.912$ & ICV (Poland) & $=6.630$ \\
\hline & ISI (Dubai, UAE & $=0.829$ & РИНЦ (Russia & $=0.156$ & PIF (India) & $=1.940$ \\
\hline & GIF (Australia) & $=0.564$ & ESJI (KZ) & $=8.716$ & IBI (India) & $=4.260$ \\
\hline & JIF & $=1.500$ & SJIF (Morocco & $=5.667$ & OAJI (USA) & $=0.350$ \\
\hline
\end{tabular}

эффективной работы; необходимость научнообоснованного нормирования труда.

Ф.У. Тейлор, бесспорно основатель scientific management. Именно он первым обнаружил «истощение» эффективности главного положения в практике управления: «инициатива поощрение» за качество работы. «В противоположность этому, утверждал Тейлор, развитие научной организации труда предлагает выработку многочисленных правил, законов, формул, которые заменят собою личное суждение индивидуального работника и которые могут быть с пользой применяемы только после того, как будет произведен систематический учет, измерения и т.д. их действия».

Нельзя не согласиться с резюме Д.М. Гвишани: ... то, что в строгом смысле этого термина называется тейлоризмом, сводится к следующему[4-5]:

1. Создание научного фундамента, заменяющего собою старые, традиционные, практически сложившиеся методы работы, научные исследования каждого отдельного ее элемента.

2. Отбор рабочих на основе научных критериев, их тренировка и обучение.

3. Сотрудничество между администрацией и рабочими в деле практического внедрения научно разработанной системы организации труда.

4. Равномерное распределение труда и ответственности между администрацией и рабочими.

Сам Тейлор так представлял гарантии качества производства и его эффективности: «Наука вместо традиционных навыков; гармония вместо противоречий; сотрудничество вместо индивидуальной работы; максимальная производительность вместо ограничения производительности; развитие каждого отдельного рабочего до максимальной доступной ему производительности и максимального благосостояния».

Попробуйте аргументировано возразить Ф. Тейлору. Не удивительно, что его взгляд на организацию и управление машинным производством гипнотизировал современников.

Существует мнение, по которому концепция Ф. Тейлора, Г. Форда, А. Фойля и М. Вебера «В основных чертах просуществовала до настоящего времени и стала моделью организации производства большинства современных предприятий. Только в 70-е годы ей на смену стала приходить другая концепция - производственная система Тойота».

Идеология «фазы отбраковки» была простой и ясной: на выходе производства должна быть только качественная продукция, встречу потребителя и бракованных изделий допустит нельзя. Основные усилия управляющих должны быть сосредоточены на контроле качества комплектующих и сборке готовой продукции. В относительной простоте концепции «фазы отбраковки» была ее надежность и относительность ее надежности, приведенная к необходимости нововведений в последующем.

Опора в идеологии качества производства на «фазу отбраковки» получила практический эффект. Было бы удивительным, если бы результат не был бы положительным. Усиление внимания за контролем качества логически предпослано в качестве условия функционирования производства. Это требование на рыночном уровне осмысления сопровождало развитие производственной деятельности на всем протяжении ее существования.

Удивляет устойчивость достигнутого пионерами разработки научного решения проблемы управления качеством производства экономического (а в известной степени и социального) эффекта.

И все же скрытая до времени сторона «фазы отбраковки» должна была проявиться. Смещения управления на фазу качественной подготовки производства - по существу же в сторону особого статуса контрольных функций, сигнализировало о возрастании соответствующих затрат на обеспечение качественной продукции.

Качество производства и качество производимой продукции составляют единое целое, но не одно и то же. Развитие производства бесспорно обусловлено качеством изготовляемых товаров. Э. Деминг справедливо во главе списка из «семи смертельных болезней» современного производства поставил «планирование производства, не ориентированное на такие товары и услуги, на которые проявляет спрос рынок».

Производство при переходе от индустриального к постиндустриальному обществу массового потребителя все больше становится функцией рынка «Покупатель всегда прав»- как бы не было известное суждение противно продавцу, вынужденному подстраиваться под спрос покупателя, он не имеет выбора. Нет выбора и у производителя, для которого «продавец» - это «покупатель».

Качество изделия - особая «песня» производства. Только «концерт» не может складываться из одной песни. Качество производства характеризуется еще и его экономической эффективностью. Погоня за качеством изделий не может быть самоцелью производства, иначе благое дело превратится в смертельную болезнь. Качество товара не способно компенсировать неэффективность производства в целом.

Повышение качества конечного продукта всегда требует затрат на его обеспечение, что становится проблемой для разработчиков 


\begin{tabular}{|c|c|c|c|c|c|c|}
\hline \multirow{4}{*}{ Impact Factor: } & ISRA (India) & $=3.117$ & SIS (USA) & $=0.912$ & ICV (Poland) & $=6.630$ \\
\hline & ISI (Dubai, UAE & $=0.829$ & РИНЦ (Russia) & $=0.156$ & PIF (India) & $=1.940$ \\
\hline & GIF (Australia) & $=0.564$ & ESJI (KZ) & $=8.716$ & IBI (India) & $=4.260$ \\
\hline & JIF & $=1.500$ & SJIF (Morocco) & $=5.667$ & OAJI (USA) & $=0.350$ \\
\hline
\end{tabular}

стратегии эффективного производства. Цели повышения эффективности производства и совершенствования качества произведенной продукции не совмещалось в концепции «фазы отбраковки», поэтому ей на смену в 20-е годы прошлого века пришла «фаза управления качеством». Ее разработчики предприняли попытку преодолеть критическое значение затрат на качество продукта, очевидное на «фазе отбраковки». Разрешить возникшее противоречие им оказалось не под силу. Удалось его смягчить. Среди новаторов реконструкции «фазы отбраковки» выделялся сотрудник отдела технического контроля американской фирмы «Вестерн Электрик» В. Шухарт, предложивший метод построения диаграмм, более известных под названием «контроль карты В. Шухарта».

В первом приближении инициатива американского специалиста выглядит достаточно радикально. В. Шухарт отказывается от ключевой схемы контроля за качеством Ф. Тейлора, Г. Форда. В центре управления качеством вместо этапа подготовки производства, на котором необходимо выбраковать некачественные изделия, оказывается сам процесс производства.

Система методов В. Шухарта была направлена на совершенствование технологического процесса, что призвано было способствовать увеличению выпуска готовой качественной продукции.

В концепции B. Шухарта изначально чувствуется диалектический подход к делу. Его предшественники старались «разложить производство по полочкам» и загрузить «полочки» так, чтобы получить искомый результат. В итоге они перегрузили одну из фланговых «полочек» и произошел перекос всей конструкции. Этап подготовки - контроля сделался наиболее затратным, в то время как главный этап - технологический попал от него в зависимость и был оттеснен на периферию процесса управления, незаслуженно пострадал.

В. Шухарт назвал «вещи» своими именами и расставил этапы согласно рангу, выделив технологический. Он рисковал, упрощая этап подготовки производства, снижением качества комплектующих. Взамен рассчитывал получить выигрыш в основном звене производства.

Вкладывая приоритетно средства в совершенствование технологии, производитель усиливает процесс производства, делает его в принципе более эффективным за счет организации и технического оснащения. Что же касается брака, то его целесообразнее отслеживать именно при организации отношений в самом производстве, опираясь на научные разработки и своевременное внедрение новинок технического процесса, в комплекте с мерами подготовки качества готовности исполнителей.
Главным объектом управления качеством концепции В. Шухарта оказывается производственный процесс. Выход из него представляет поток измерений параметров качества отдельных изделий.

Прежнюю фордовскую цель «попасть в допуск» В. Шухарт отправляет на «пенсию». Идея Г. Форда свое отработала, пробудила новое мышление. Ей на смену В. Шухарт формирует тандем целей: обеспечение устойчивости процесса и уменьшение вариаций стабильности. Наличие вариаций $\mathrm{B}$. Шухарт считал естественным образованием. Он даже вывел критерий качества процесса - устойчивость процесса следует рассматривать в статистическом смысле. Вариации параметров изделий есть ничто иное, как реализация устойчивого случайного процесса, функция распределения которого сохраняется постоянной в течение определенного времени.

B. Шухарт полагал, что вариации параметров изделий являются следствием действия двух групп причин: особых и общих. Особые коренятся в нарушении хода производственного процесса. Они выявляются при помощи контрольной карты и устраняются на основе показаний такой карты.

Общие причины заложены в недрах самого процесса. Их много, но в отдельности они не существенны. Опасность таится в сумме действия подобных причин. Общие причины вариации параметров изделий составляют предмет заботы менеджеров, часто высокого уровня и квалификации. Своими исследованиями и действиями они способны ограничить действия общих причин. При этом В. Шухарт сделал два весьма ценных вывода, которыми следует руководствоваться управляющим производства.

Во-первых, поиск виновных необходим, однако, найдя виновных, мы редко способны повлиять на ситуацию. Необходимо искать причины несоответствия и устранять их, вовлекая в этот процесс всех его участников.

Во-вторых, источником дефектов и несоответствий становятся вариации процессов. Уменьшение вариаций в системе управления качеством В. Шухарта - комплексная цель. Связывая количество вариаций с организацией производственного процесса, В. Шухарт ясно сознавал, что для сокращения вариаций необходима новая конфигурация отношений людей, занятых в производстве. Суть новой конфигурации должна отражаться в товарищеском сотрудничестве. Люди самой особенностью производства сплачиваются в команды [9].

Система В. Шухарта - серьезный шаг вперед в сравнении с системой Ф. Тейлора. Ф. Тейлор акцентировал внимание на механизме действия, а В. 


\begin{tabular}{|c|c|c|c|c|c|c|}
\hline \multirow{4}{*}{ Impact Factor: } & ISRA (India) & $=3.117$ & SIS (USA) & $=0.912$ & ICV (Poland) & $=6.630$ \\
\hline & ISI (Dubai, UAE & $=0.829$ & РИНЦ (Russia & $=0.156$ & PIF (India) & $=1.940$ \\
\hline & GIF (Australia) & $=0.564$ & ESJI (KZ) & $=8.716$ & IBI (India) & $=4.260$ \\
\hline & JIF & $=1.500$ & SJIF (Morocco & $=5.667$ & OAJI (USA) & $=0.350$ \\
\hline
\end{tabular}

Шухарт - на механизме взаимодействия людей во всем спектре их отношений: техническом, экономическом, психологическом.

Абсолютно прав Б.С. Алешин с соавторами утверждая: «Такое понятие, как «допуски» (одно из важнейших изобретений Ф. Тейлора) несомненно, остается в практике работы. «Допуски»- это форма, язык требований к качеству, результат планирования качества. Меняется другое: противопоставление задач планирования, исполнения, контроля и корректирующих действий. Такие задачи выполняются командами ...»

Сравнение двух названных выше систем экономического управления качеством можно представить следующим образом (рисунок. 2).

Вместе с тем отметим, что идеи и методы В. Шухарта продолжают стремление Ф. Тейлора поставить управление качеством на научную основу, использовать именно научные методы в организации производства. Но и здесь В. Шухарт «опережает» Ф. Тейлора.

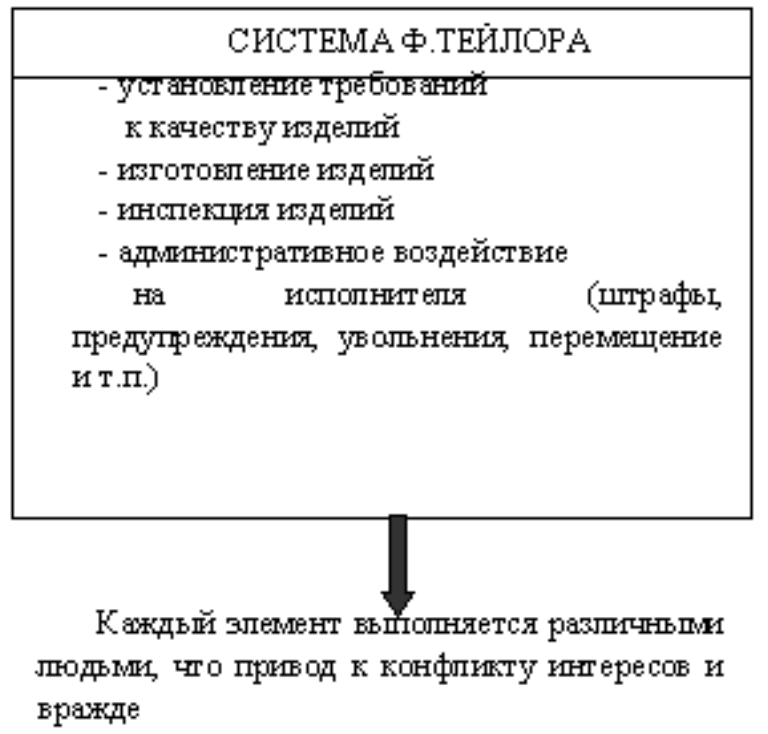

Наука (и научные методы) для Ф. Тейлора, Г. Форда сводились к тем ее представлениям, которые позволяют количественно измерить механические действия отдельно взятого исполнителя, найти оптимальный маршрут движений и взять его под эффективный контроль, предварительно загрузив по полной программе заданиями. «Классическая» (тейлоровская) теория управления качеством своей опорой имела центробежные силы и движения и производства: разделение труда, специализацию действий, индивидуальность исполнителя. Эту ее односторонность поняли критики.

В. Шухарт счёл явным упрощением механистический взгляд на развитие производства вообще и управление качеством в частности. Процесс производства не только результирует взаимодействия центробежных и центростремительных сил - индивидуальных и коллективных действий: он не допускает сведение происходящего в нём к отношениям механического типа..

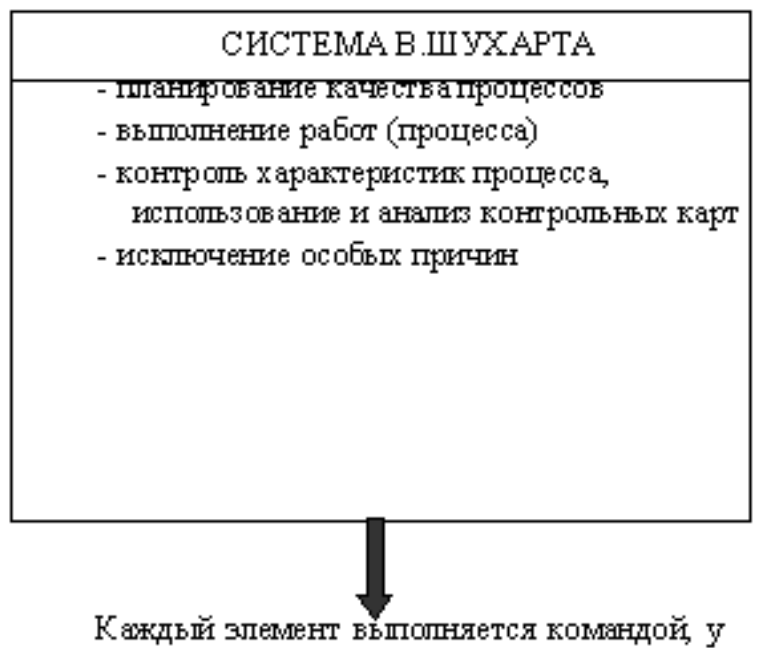

которой есть общая цель - снгженпе в ариаций

Рис. 2. Сравнение систем Тейлора и Шухарта.

В производстве участвует человек как субъект действий и отношений. Более того, человек в качестве субъекта труда - решающий фактор производства. Развитие производства должно опираться на развитие субъекта и отношений субъекта и отношений субъектов.

Субъективный потенциал в виде индивидуальных знаний, умений и стремлений главный резерв эффективности производства, который наука помогает активировать и организовать должным образом. В таком понимании наука включает в себя социальную и гуманитарную составляющие.
Органический дефект «классической» теории управления качеством производства упрощение представление и природе человеческого поведения в организации. В. Шухарт это понял, объяснил, как мог, и рассчитывал быть понятным и востребованным практическим менеджментом.

Новые идеи В. Шухарта не прошли незамеченными бизнесом, но, видимо, инерциальные силы движения бизнеса настолько велики, что идеи начинают действовать на него только со временем.

Короткий путь к прибыли по привычке мыслился самым простым. Всякое усложнение 


\begin{tabular}{|c|c|c|c|c|c|c|}
\hline \multirow{4}{*}{ Impact Factor: } & ISRA (India) & $=3.117$ & SIS (USA) & $=0.912$ & ICV (Poland) & $=6.630$ \\
\hline & ISI (Dubai, UAE & $=0.829$ & РИНЦ (Russia & $=0.156$ & PIF (India) & $=1.940$ \\
\hline & GIF (Australia) & $=0.564$ & ESJI (KZ) & $=8.716$ & IBI (India) & $=4.260$ \\
\hline & JIF & $=1.500$ & SJIF (Morocco & $=5.667$ & OAJI (USA) & $=0.350$ \\
\hline
\end{tabular}

сопряжено с дополнительными расходами. Оправдаются ли они? К тому же измерить механику действия намного проще, чем мотивацию деятельности.

Не удивительно, что и спустя почти полвека Дж. Марч и Г. Саймон отмечали: в США широко распространены два взгляда на положение людей в организации: «рассмотрение служащего в качестве инертного инструмента, выполняющего указанное ему назначение, и трактовка персонала в качестве чего-то данного, а не как переменной величины в системе». С ними солидарен еще один авторитетный ученый М. Хейр: «Существуют подразумеваемые допущения относительно человека, на которых, как мне представляется, зиждется классическая теория организации и управления: он ленив, близорук, эгоистичен, предрасположен к ошибкам, не умеет судить здраво и даже может быть немного нечестен». В тексте М. Хейра разъясняется, что классическое толкование организации управления по-прежнему весьма популярно в практическом менеджменте.

Три основных положения «классической» теории управления качеством не изжиты до сих пор. Они продолжают впечатлять, грея душу патронов, лаская их самосознание, подкрепляя самоуверенность в своей избранности. Все так хорошо разложено по своим местам: работник исполнитель, по сути «рациональное животное» с четко выраженной доминантой максимизировать экономические выводы; «каждый индивид реагирует на экономические стимулы как изолированный индивидуум»; «к людям, как к машинам, можно относиться стандартизированным образом».

У В. Шухарта было много сторонников, оставивших свой собственный заметный и оцененный след: М. Фоллет, Э. Мэйо, Ч. Барнард, Ф. Ротлисбергер, Г. Саймон. Тридцатые годы прошлого столетия ознаменовались «гуманистическим вызовом» «проповеди административной ответственности».

В теории события разворачивались согласно логическому сценарию. Практика же не была столь восприимчива к переменам во взглядах, поэтому эффективность нового подхода к экономическому управлению качеством оставляла место на раздумье о сложности взаимоотношений теории и практики.

Построение самой экономики тормозило тотальность внедрения прогрессивных идей. Чтобы человек развернулся в качестве субъекта производства - мобилизовал свои способности, знания, надо обязательно, чтобы экономика повернулась «лицом» к человеку, обрела «человеческое лицо». По-другому нельзя вписать таланты личности в интерьер производства, сделать их заинтересованными сослуживцами.

Диалектика предупреждает: истина конкретна. Теория эффективна в конкретно-исторических рамках. Ее жизнь может быть долгой или короткой, но всегда конечной. Элементы же теории и опыт ее эксплуатации, выраженный в исторических уроках, продолжают работать, воплощаясь в другие, актуальные теории и практические действия.

Сегодняшняя экономическая составная качества не может не учитывать приобретения В. Шухарта, М. Фоллет, Г. Саймона и всех тех, кто доказывал необходимость вовлечения в борьбу за качество способностей субъекта мыслить и увлекаться делом. В частности, на наш взгляд, сохраняется сила «контрольных карт» В. Шухарта. Они просты и дают возможность мониторинга качества процесса и деятельности исполнителей. И для исполнителей они понятнее, чем далеко не всегда понятное неудовольствие управляющего, поэтому мы приводим их образец (рисунок 3). 


\begin{tabular}{|c|c|c|c|c|c|c|}
\hline \multirow{4}{*}{ Impact Factor: } & ISRA (India) & $=3.117$ & SIS (USA) & $=0.912$ & ICV (Poland) & $=6.630$ \\
\hline & ISI (Dubai, UAE & $=0.829$ & РИНЦ (Russia) & $=0.156$ & PIF (India) & $=1.940$ \\
\hline & GIF (Australia) & $=0.564$ & ESJI (KZ) & $=8.716$ & IBI (India) & $=4.260$ \\
\hline & JIF & $=1.500$ & SJIF (Morocco) & $=5.667$ & OAJI (USA) & $=0.350$ \\
\hline
\end{tabular}

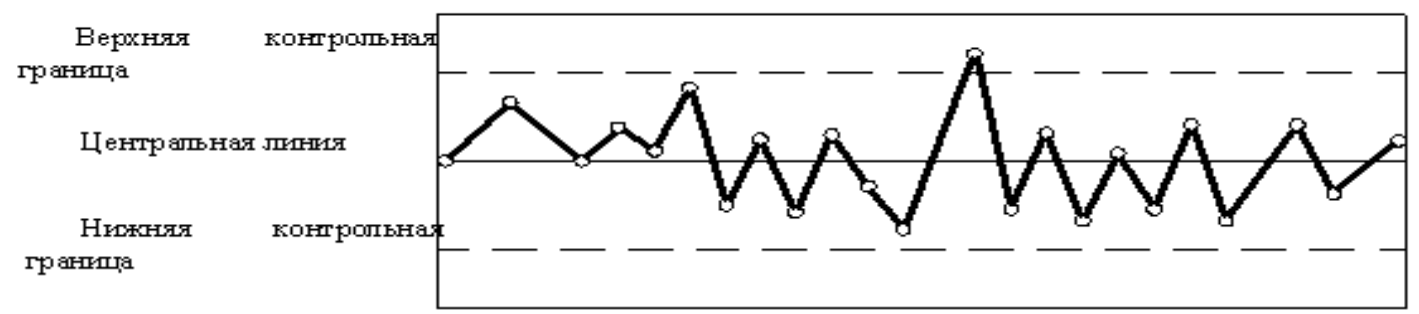

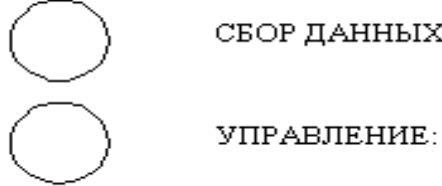

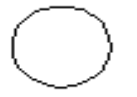

АНАЛИЗ УЛУЧШЕНИЕ

\section{Co6ерите данные и нане сите иx на карту}

Вычислите пробные контрольные границы по данньп о процессе.

Определите особые причины вариации и возде йствуйте на них

Оцените вариации по особым причинам и примите меры по их снижениг

Эти три фазып повт оряйте для непрерьпного упучшения процесса
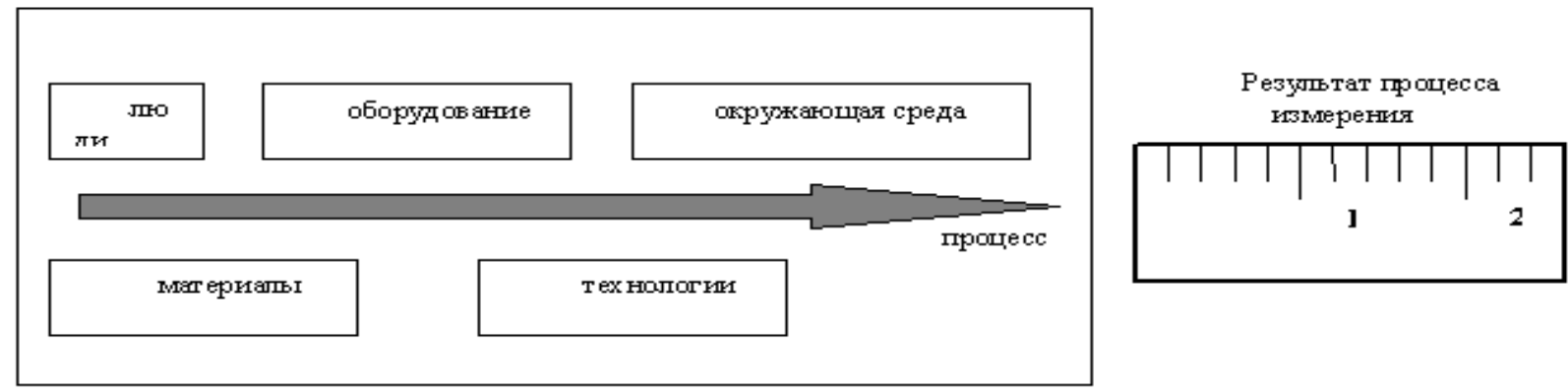

Рис. 3. Контрольная карта В. Шухарта.

Разработав модель устойчивого процесса, В. Шухарт значительно расширил возможности научного анализа качества производства, благодаря чему раскрылись те стороны и этапы производства, которые оставались в тени в «классической» концепции. Он ввел в характеристику качества производства понятие «корректировки процесса по данным его измерений», которое вполне модно рассматривать как конкретизацию применительно к управлению качеством понятия «обратная связь».

В теории случайных процессов количественной мерой зависимости последовательности случайных величин является коэффициент автокорреляции, принимающий значения от 0 до 1 . при его значениях, близких для соседних наблюдений к 0 (на практике $<0,2-$ 0,3), процесс считается «белым шумом». Если же значения коэффициента автокорреляции близки к 1 , то для данного процесса следует использовать различные системы регуляции с обратной связью.
Не трудно увидеть в концепции Шухарта стремление теоретически осмыслить специфическое состояние массового производства своего времени. Он пытался взглянуть на конвейер глазами науки. И ему немало удалось сделать. По крайней мере, идеи В. Шухарта и в наши дни, хоть и постарели, но все еще жизнеспособны. При творческом подходе они дают хороший результат.

Замечательным вкладом в практику управления качеством стало создание аудиторской службы по качеству, функция которой существенно отличалась от задач, стоявших перед отделами технического контроля Ф. Тейлора. Она занималась не разбраковкой, а проверкой работоспособности системы обеспечения качества путем контроля небольших выработок из партий изделий. Тем самым В. Шухарт нашел путь сокращения расходов на качество, несоразмерно увеличившихся при организации производства по рекомендациям Ф. Тейлора. 


\begin{tabular}{|c|c|c|c|c|c|c|}
\hline \multirow{4}{*}{ Impact Factor: } & ISRA (India) & $=3.117$ & SIS (USA) & $=0.912$ & ICV (Poland) & $=6.630$ \\
\hline & ISI (Dubai, UAE & $=0.829$ & РИНЦ (Russia & $=0.156$ & PIF (India) & $=1.940$ \\
\hline & GIF (Australia) & $=0.564$ & ESJI (KZ) & $=8.716$ & IBI (India) & $=4.260$ \\
\hline & JIF & $=1.500$ & SJIF (Morocco & $=5.667$ & OAJI (USA) & $=0.350$ \\
\hline
\end{tabular}

Однако оригинальное мышление В. Шухарта и его организаторский талант не разрешили старого противоречия между необходимостью обеспечить производству эффективность и потребностью рынка в качественном товаре, а самого производства в качественном сырье и комплектующих. Каждый производственный процесс имеет предел выхода качественных изделий. Этот предел заложен не в процессе. Он - атрибут системы, практикуемой на предприятии, порождение всей совокупной деятельности, особенностей организации труда и управления производством, в том числе и качеством производства. Приближение предела приводит к нарастанию основного противоречия. Обеспечение качества требует все больше средств, что ведет к снижению эффективности производства.

В пятидесятые годы формируется новая концепция менеджмента качества. Ее вдохновителем был Э. Деминг. Название очередного этапа в развитии философскоэкономического понимания управления качеством производства подчеркивает еe сущность «фаза постоянного повышения качества».

Предложенная Э. Демингом версия обеспечения качества производства оказалась долгожителем, просуществовав «в авторитете» почти полвека, до середины девяностых годов. Такая продолжительность практической актуальности концепции Э. Деминга объясняется, как нам кажется, тем, что она была умело «посажена» на основание, подготовленное В. Шухартом, и представляя собой по форме уже программный продукт.

Программа менеджмента Э. Деминга выстроена на трех аксиомах, ориентированных на производственную практику:

первая практическая аксиома утверждает, что любую деятельность нужно определять как технологический процесс, из чего следует вывод о возможности ее совершенствования;

вторая практическая аксиома сформирована Э. Демингом так: производство имеет две формы состояния - находится в стабильном или нестабильном состоянии. В обоих случаях недостаточно решать частные проблемы, необходимы фундаментальные изменения;

третья практическая аксиома Э. Деминга такова: высшее звено менеджмента предприятия во всех случаях обязано принимать на себя ответственность за результат.

Практической конкретности аксиомы Э. Деминга достигают в рамках специальной программы менеджмента, обобщающей теоретический и реальный опыт организации управления качеством производства. Программу представляют несколько уровней осмысления и практического воплощения идей: «Четырнадцать пунктов», «Семь смертельных болезней», «Трудности и фальстарты», «Цепная реакция по Демингу», «Принцип постоянного улучшения (цикл Деминга)».

Особый интерес для практики совершенствования управления качеством на предприятиях представляют предпоследний и последний разделы программы. «Цикл Деминга» - это по сути дела схема, предложенная В. Шухартом, что признавал и Деминг. «Цепная реакция»- продукт собственного творчества Э. Деминга.

В цикле Деминга-Шухарта закольцованы четыре этапа: наблюдение, разработка улучшающих ситуацию мероприятий, внедрение и анализ. Задача менеджера по качеству на первой из них - сбор информации и определение слабых звеньев производства, требующих перестройки. На втором этапе руководитель разрабатывает организационные меры, направленные на изменение положения. В числе них и подключение всех исполнителей за счет мотивации. Следующий этап - внедрение и наблюдение за процессом модернизации. Завершает цикл этап анализа полученных от внедрения результатов, наращивание опыта для повторения цикла.

Наверное, графически цикл ДемингаШухарта лучше всего демонстрирует спираль развития, каждый виток спирали - это относительно замкнутый цикл действий. На него «опирается», продолжая общий процесс, следующий виток. Если бы не традиция называть подобные открытия именами авторов, то цикл Деминга-Шухарта назвали бы «цикл витка спирали» управления качеством. Цикл ДемингаШухарта бесспорно актуален и сейчас для совершенствования организации производства, так как в нем отражен универсальный закон построения менеджмента.[6-7]

Нельзя не воздать должное Э. Демингу и за разработку им «цепной реакции» в управлении качеством, приведенной на рисунке 4 . В ней он сцепил экономические и социальные действия, подчеркнув характер исторического времени. 


\begin{tabular}{|c|c|c|c|c|c|c|}
\hline \multirow{4}{*}{ Impact Factor: } & ISRA (India) & $=3.117$ & SIS (USA) & $=0.912$ & ICV (Poland) & $=6.630$ \\
\hline & ISI (Dubai, UAE & $=\mathbf{0 . 8 2 9}$ & РИНЦ (Russia) & $=0.156$ & PIF (India) & $=1.940$ \\
\hline & GIF (Australia) & $=0.564$ & ESJI (KZ) & $=8.716$ & IBI (India) & $=4.260$ \\
\hline & JIF & $=1.500$ & SJIF (Morocco) & $=5.667$ & OAJI (USA) & $=0.350$ \\
\hline
\end{tabular}

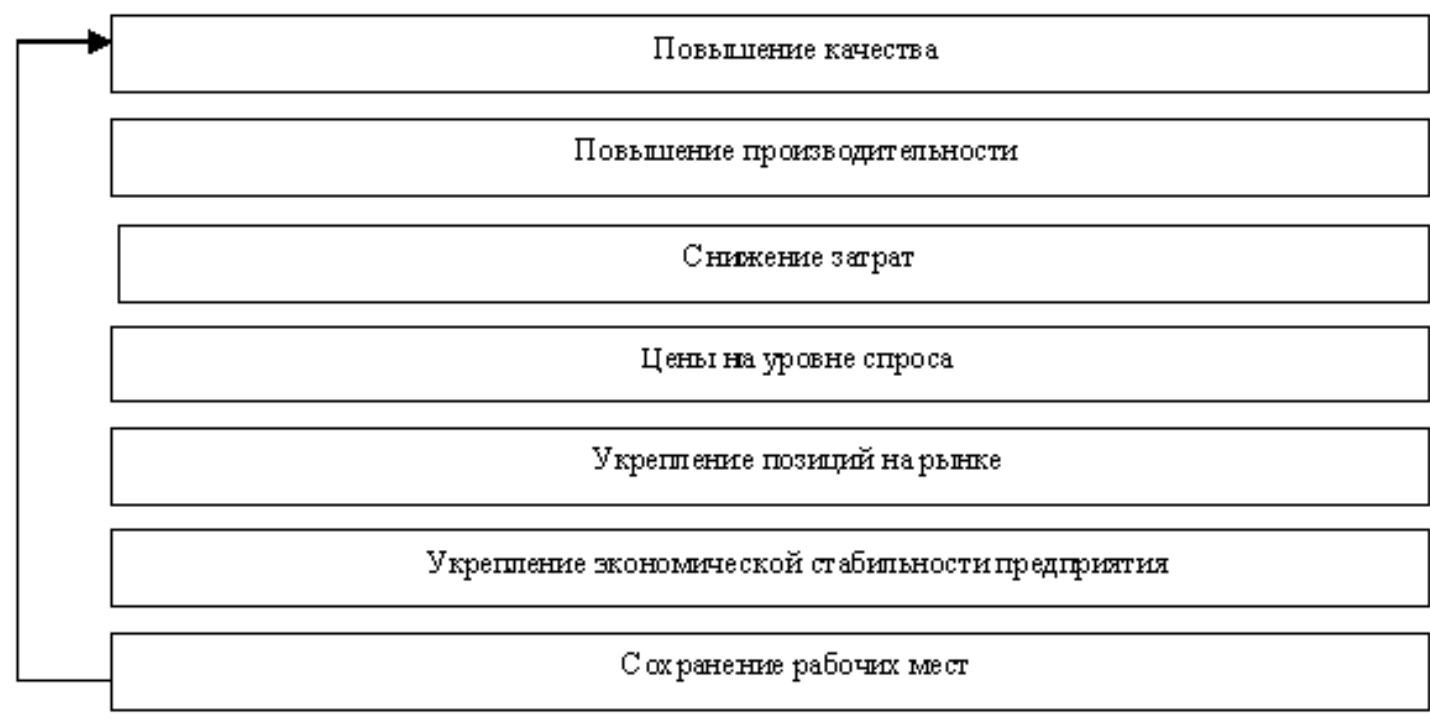

Рис 4. «Цепная реакция» по Э.Демингу.

Расцвет творчества Э. Деминга связан с возрождением экономики Японии. Правительство и промышленники страны поверили аргументации Деминга и он заслуженно разделил c ними славу «японского чуда». Его вклад очевиден и в достижении японских специалистов в области повышения качества производства, которые четко выделены в исследовании Б.С. Алешина с соавторами:

«1. Многолетнее, последовательное и целеустремленное решение проблем качества на основе всего передового, что накапливает теория и создает практика в этой области.

2. Последовательное и настойчивое налаживание системы изучения запросов потребителя - $\quad$ (профилактика главной «смертельной болезни экономики» по классификации Э. Деминга - ред.), формирование уважительного отношения к потребителю и его требованиям вплоть до культа потребителя (потребитель всегда прав - ред.) потребитель (при этом) понимается в широком смысле, как следующее звено технологической цепочки.

3. Стремление к всеобщему участию в достижении качества, от руководителей высшего звена до исполнителей конкретных работ.

4. Понимание того, что даже отлично отлаженная система организации труда без постоянных проверок и совершенствования теряет эффективность.

5. Организация работ по обеспечению качества непосредственно мастерами и бригадирами. Обучение, включая специальные программы национального телевидения, национальные конференции для мастеров и бригадиров.

6. Особое внимание - на мобилизацию физического и интеллектуального потенциала рабочих. Кружки качества - групповой анализ положения дел на конкретном участке и выработка предложений по улучшению качества и повышению эффективности процессов, производства.

7. Широкое развитие постоянно действующей системы пропаганды значения высокого качества продукции для обеспечения высоких темпов экономического роста.

8. Государственное влияние на кардинальное улучшение качества, прежде всего экспортной продукции, включая обязательную государственную сертификацию. Попытка продать на экспорт несертифицированную продукцию рассматривается как контрабанда. Государственная поддержка экспорта, помощь в продвижении товаров на рынки других стран».

Мы сознательно не стали сокращать фрагмент, описывающий японскую практику создания системы управления качеством, потому что в нем, как к зеркале, видны российские просчеты, именно российские, так как, объявив РФ преемницей СССР, российские политики и приближенные к ним ученые-экономисты в 90-е годы планомерно уничтожали социалистический опыт строительства качества производства вместо того, чтобы его рационально модифицировать. Качество в 90-е годы никому из тех, кто должен за него отвечать, было не нужно. Экономику переориентировали на сырье, качество которого либо определяется 


\begin{tabular}{llllll} 
& ISRA (India) $=3.117$ & SIS (USA) $=\mathbf{0 . 9 1 2}$ & ICV (Poland) & $=\mathbf{6 . 6 3 0}$ \\
Impact Factor: & ISI (Dubai, UAE) $=\mathbf{0 . 8 2 9}$ & PUHЦ (Russia) $=\mathbf{0 . 1 5 6}$ & PIF (India) & $=\mathbf{1 . 9 4 0}$ \\
& GIF (Australia) $=\mathbf{0 . 5 6 4}$ & ESJI (KZ) $=\mathbf{8 . 7 1 6}$ & IBI (India) & $=\mathbf{4 . 2 6 0}$ \\
& JIF & $=\mathbf{1 . 5 0 0}$ & SJIF (Morocco) $=\mathbf{5 . 6 6 7}$ & OAJI (USA) & $\mathbf{0 . 3 5 0}$ \\
\hline
\end{tabular}

естественным происхождением, либо «компенсируется» реализованным качеством.

Сравнение экономической политики Японии 50-х и последующих годов с экономической политикой РФ 90-х, анонсированной возрождением России, приводит к грустному заключению: громкие заявления редко соответствуют делам. Интересы Отечества в период ельцинских демократических реформ политиков волновали меньше всего, а о качестве вообее не заботились, растранжирив предшествующие национальные приобретения. Впрочем, политическую оценку этого этапа нашей истории давно дали, и нас интересует та часть теории, которая непосредственно работает на экономику страны. В таком контексте уместно «пройтись» по ряду японских достижений, имея в виду возможность, извлечь из них практические политико-экономические уроки. Тотальный вывод сомнений не вызывает: эффективность экономики определяется не качеством произведенного товара, а его ассортиментом и качеством. Переход количества в качество могли ожидать лишь те, кто упростил диалектику до глупости. В новое качество превращается не количество - качество и только оно.

Учителями японцев были американцы, однако учились японцы очень серьезно на опыте - и положительном и отрицательном советском. Мы же до сих пор не определились практически. Наши нынешние декларации, сертификации весь мир воспринимает скептически. Кто не умеет ценить и использовать собственные достижения, не способны по достоинству освоить и чужие.

В Японии отношение к качеству стало национальной идеей, и воплотилась в форму «борьбы», в которой престижно участвовать было всем от вахтера до генерального директора. Сложилась система взаимных интересов, поддерживаемся финансами, организационно (строительство карьеры) и духовно.[8-9]

\section{Основная часть}

Современную экономику все чаще называют «умной», «рачительной», инновационной. Это более понятное определение в сравнении с «постиндустриальной», но насколько оно адекватно характеризует ее состояние - вопрос не праздный. Характер проявляется в развитии, обусловливает планирование экономической политики. Последний кризис однозначно свидетельствует о том, что, во-первых, планирование не просто совместимо с рыночным способом хозяйствования, - оно необходимо для предупреждения и смягчения негативных явлений, рождаемых безраздельной экономической свободой, граничащей с произволом; во-вторых, продолжающийся кризис вскрыл ограниченность стремления представить построенную экономику «умной». Умная экономика должна быть, к сожалению только одним умом ее построить невозможно.

Центральная фигура товарного производства не финансы, как считают многие политики, в том числе и отечественные. Деньги - это всего лишь эквивалент товара и навсегда им останутся. Товар же создает труд, являющийся, в свою очередь так же товаром. Следовательно, корнями движение производства уходит в совокупное выражение человеческой деятельности, прежде всего, работу сознания, его потенциал.

Ум же не эквивалентен сознанию. УМ инструмент строительства сознания. «Умное сознание - знающее, хитрое, мобильное - но не более. Уму нужен, как любой силе, вектор, направляющий приложение ума, строительство сознания. Роль вектора играют ценности: профессиональные, национальные, общечеловеческие. Сознание сплавляет их в уникальном личном выражении. «Умная» экономика - никакая, если не поставить ее на ценностный фундамент.

Главное в личности - решающего фактора социального воспроизводства - eе нравственность. Не всем дано быть топ менеджерами, генеральными конструкторами, вип-персонами в политике. Кто-то должен работать мозгами, кто-то руками. Беда приходит, когда «мозги» и «руки» делаются липкими и к ним пристает то, что не положено. Безнравственность подрывает основы профессиональной культуры, и профессиональная деятельность из созидательной силы трансформируется в свою противоположность - разрушает созданное. Экономика «умная» может оказаться страшной реальностью, если она и далее будет безнравственной. Мы не утописты и не идеалисты, хорошо понимаем конкретноисторическое положение нравственности. Сейчас речь идет не о равенстве и братстве исключительно о совести и ответственности. Экономика может и должна быть, прежде всего, ответственной и «совестливой», потом уже «умной».

Пока свободная конкуренция подчинена расчетам - как эффективнее обмануть партнера, потребителя, конкурентов и... государство; строится на коррупции и лоббиризации, манипулировании работой источников массовой информации, естественные для развития рынка. Циклические, экономические кризисы будут прирастать неестественными - системными. Системообразующий фактор последних бессовестность и безответственность крупнейших производителей. 


\begin{tabular}{|c|c|c|c|c|c|c|}
\hline \multirow{4}{*}{ Impact Factor: } & ISRA (India) & $=3.117$ & SIS (USA) & $=0.912$ & ICV (Poland) & $=6.630$ \\
\hline & ISI (Dubai, UAE & $=0.829$ & РИНЦ (Russia & $=0.156$ & PIF (India) & $=1.940$ \\
\hline & GIF (Australia) & $=0.564$ & ESJI (KZ) & $=8.716$ & IBI (India) & $=4.260$ \\
\hline & JIF & $=1.500$ & SJIF (Morocco & $=5.667$ & OAJI (USA) & $=0.350$ \\
\hline
\end{tabular}

А что же должно было предпринять государство, призванное быть социальным гарантом для демократического общества и защитником прав его граждан. Оно вынуждено было «подлить масло в огонь»- субсидировать обанкротившийся на аферах бизнес, чтобы избежать экономического и социального коллапса. Правда, европейские лидеры одновременно направили к «источникам пожара» «пожарных» - поставили дальнейшую работу проштрафившихся фирм в зависимость от нравственных начал - ввели нравственный и финансовый регламент, призванный отрезвить потерявших всякую меру дельцов. Симптоматично: именно Франция и Германия инициаторы жесткого нравственно-финансового мониторинга - первыми почувствовали признаки экономического оздоровления. Англия и США, пораженные в большей мере коррупцией и менее склонные к нравственному диктату, продолжают пожинать плоды свободы от совести и социальной ответственности своих магнатов.

Россия, как и следовало ожидать, упустила реальную возможность использовать кризис для активизации национальной промышленности. Сначала влили финансы в банки, потом очень невнятные действия предприняли с целью разбудить совесть и ответственность банкиров. Будто забыв, что банкир без ликвидности и с ликвидностью, - «две большие разницы ». Был шанс за счет национальных фондов заставить банки быть финансовым рычагом подъема промышленного производства, науки, технического творчества в стране.

Изменить ситуацию можно, объединив ум,его нам не занимать, и совесть, - дефицит которой за годы демократических реформ вырос удивительно быстро. Причину такого расклада следует искать в экономическом беспределе и непропорциональном росте управленческого аппарата. Странно получается: чем больше чиновников, тем менее эффективно управление, - динамика очевидна, а курс прежний. Наше отставание от кого-то - дело естественное. В историческом «пелетоне» субъекты имеют свое место, меняются местами - так и должно быть. Для национального развития трагедия отстать от времени, потерять место в «пелетоне». В «восьмерке» мы были - восьмыми, но в «восьмерке».

Какими мы будем через 5-10 лет в «двадцатке», покажет время. Экономически мы уже там не восьмые, сохраняя пока место в десятке. А ведь еще на памяти большинства россиян пора, когда за СССР была вторая строчка мирового экономического рейтинга.

История не возвращается, однако это не повод забывать историю. Каким бы продолжение истории не было, оно есть ее продолжение. Отказавшись от национальных традиций, можно оказаться у «разбитого корыта». Фальсифицируется не только Вторая мировая война, искажаются, замалчиваются научнотехнические и индустриальные достижения страны. Подрывается вера в национальные силы, способность народа вернуть утраченные позиции.

Нынешняя ситуация - архисложная, тем не менее она не критичнее тех переломных моментов отечественной истории, что казались безысходными: разрухой после гражданской войны, потерей наиболее развитых территорий в первые годы Великой Отечественной войны, усугубившейся колоссальными жертвами среди населения трудоспособного возраста, специалистов. Тогда не было финансов, имеющихся в качестве начального капитала сегодня. Стало быть, решение проблемы создания современной экономики упирается технически в необходимость разработки эффективной системы управления и контроля за исполнением принятых программ.

Программа пришла на смену плану. А что пришло на смену ответственности за срыв плана? Отсутствие действенной системы контроля - самый серьезный дефект нынешней экономической политики, позволяющей дилетантам руководить. Возрождение экономики в существующих условиях профессиональной безответственности невозможно. Только профессионализм и связанная с ним ответственность за дело, которому служишь, способны совершить необходимый переход в новое экономическое качество, построить экономную и мобильную экономику на базе всемерного развития науки, стимулирования технического прогресса и совершенствования профессиональной подготовки кадров.

Экономику XXI века можно называть поразному. Не в названии суть определения - в содержании понятия. Дивертификация названий показывает многогранность современной экономики. Методологически значимо выделить в этом множестве ведущее звено, либо звенья. Бесспорно среди явных претендентов находится качество экономики.

Присутствие качества в характеристике любого явления инвариантно, так как качество соединяет в себе наиболее существенные его признаки. В то же время следует четко понимать, что само качество изменяется - оно исторически конкретно. Соответственно меняется - должно меняться - и представление о качестве. С первых попыток А. Файоля, Г. Форда и Ф. Тейлора поставить качество товара под контроль, увенчавшихся серьезным успехом, теоретически стало ясно: будущее качества экономики за деятельностью. Определяющим для экономики будет не столько качество принятого к производству товара, сколько качество организации и управления качественным его 


\begin{tabular}{|c|c|c|c|c|c|c|}
\hline \multirow{4}{*}{ Impact Factor: } & ISRA (India) & $=3.117$ & SIS (USA) & $=0.912$ & ICV (Poland) & $=6.630$ \\
\hline & ISI (Dubai, UAE & $=0.829$ & РИНЦ (Russia) & $=0.156$ & PIF (India) & $=1.940$ \\
\hline & GIF (Australia) & $=0.564$ & ESJI (KZ) & $=8.716$ & IBI (India) & $=4.260$ \\
\hline & JIF & $=1.500$ & SJIF (Morocco) & $=5.667$ & OAJI (USA) & $=0.350$ \\
\hline
\end{tabular}

производством. Для ремесленничества и мелкосерийного производства качество образца и товарной продукции объединяются с технологией, как правило, неизменной. Здесь качество полностью зависит от мастерства владения техникой и соблюдения заявленной технологии в условиях ограниченных масштабов производства. Часто мастер, технолог, менеджер и маркетолог одно и то же лицо.

Г. Форд впервые поставил производство сложного продукта на поток, разделив операции и ответственность, и, тем самым, определил поворот в судьбе качества. Отныне судьба качества определялась «привнесенными» факторами - организацией производства, управлением и контролем. На первый план вышло не мастерство непосредственного производителя, а умение мастерски организовать производство, включая и его расширенное воспроизводство, то есть снабжение, маркетинг, кадровый менеджмент.

Дивертификация деятельности раскрыла ее особое положение в достижении качественного результата. Вторая мировая война подтвердила: кадры и управление решают все!

С 1950-х годов резко интенсифицируется поиск программ управления качеством через качество деятельности. Если в начале XX века актуальность приобрела техническая регламентация продукта и составляющих, то спустя полвека произошло качественное уточнение значения технической регламентации. В эпицентре интересов оказалась уже техническая регламентация организации и управления производством, что подтверждает и современная международная система регламентации качества.

Смещение центра тяжести в понимании экономической политики, нацеленной на обеспечение качественной устойчивости производства, в сторону технической регламентации деятельности не прошло без издержек и тупиковых маршрутов, что в принципе было ожидаемым. Деятельность, объединенная производством, не однородная и не автономная, поэтому решение проблем «уткнулось» в методологические и теоретические «недоделки» профессионального мышления.

Концепция «ключевых видов деятельности» было обоснована впервые А. Фейгенбаумом. В 1951 году вышла его книга «Всеобщий контроль качества». ИСО 9000 и ИСО 14000 разрабатывались уже на базе предложений
А. Фейгенбаума. Предполагалось, что обе серии международных стандартов помогут перейти от «предприятий - конгломератов» к « предприятиям - системам».

В процессе развития промышленного производства под влиянием научно-технического прогресса ускоренно сформировалось и обострилось противоречие в темпах изменения материальной стороны и эволюции управленческой мысли, касающейся организации и гармонизации производственного процесса. Последнее явно не поспевало за первым, тормозя прогресс, увеличивая риски и издержки. Жесткость централизованного планирования только ухудшало ситуацию, чем и объясняется застой 1970-х годов и спад в 1980-е годы. Организационная схема «предприятия конгломерата» плохо вписывалась в переход к системной организации работы предприятия, прежде всего потому, что не активировала инициативу, творческий потенциал. Не случайно «ударниками», «новаторами», «рационализаторами» в СССР преимущественно занимались партийная, комсомольская, профсоюзная организации, стоявшие по сути дела за рамками непосредственного производства и образовывавшими надстройку над ним.

Упрощенно организационная схема такого предприятия выглядит следующим образом (рисунок 5).

Схема построения управления, в которой основные производственные звенья функционально автономны и связаны опосредственно через общего управляющего, противосистемна. Когда кто-то, чтото проектирует, другие это должны производить, третьи - контролировать качество, четвертые сбывать продукцию на рынке, разобщает участников производства, блокируют творческий альянс. Все являются номинальными соучастниками процесса и слабо представляют кто, что и зачем делает. Отсутствует командный дух, каждый действует сам по себе, на свой страх и риск, нередко за счет коллег, подставляя последних.[1011]

Фундаментальное заблуждение менеджеров «предприятий-конгломератов» заключается в уверенности, что их «мозгов» должно хватить для своевременного распознания и выправления форс-мажоров в производственном процессе. 


\begin{tabular}{|c|c|c|c|c|c|c|}
\hline \multirow{4}{*}{ Impact Factor: } & ISRA (India) & $=3.117$ & SIS (USA) & $=0.912$ & ICV (Poland) & $=6.630$ \\
\hline & ISI (Dubai, UAE & $=0.829$ & РИНЦ (Russia) & $=0.156$ & PIF (India) & $=1.940$ \\
\hline & GIF (Australia) & $=0.564$ & ESJI (KZ) & $=8.716$ & IBI (India) & $=4.260$ \\
\hline & JIF & $=1.500$ & SJIF (Morocco) & $=5.667$ & OAJI (USA) & $=0.350$ \\
\hline
\end{tabular}

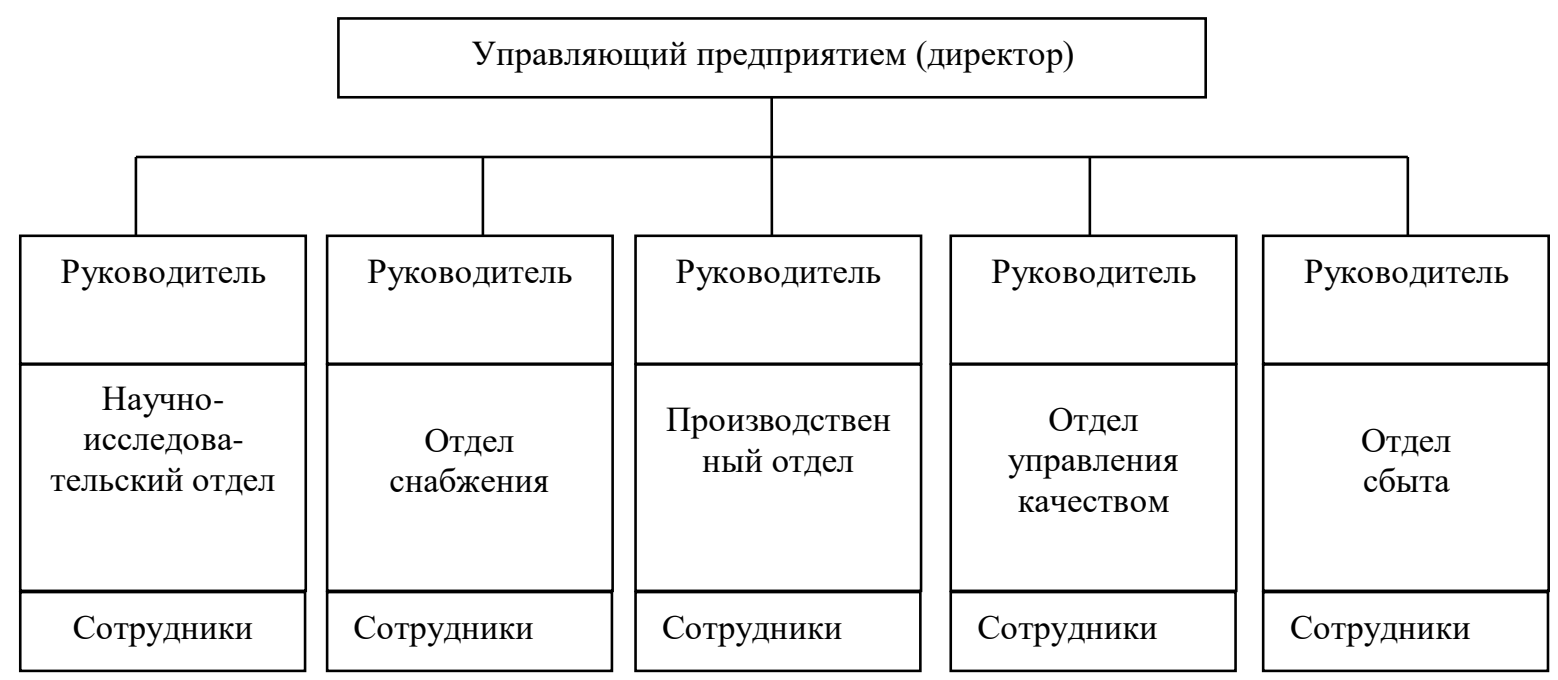

Рис.5 Организационная схема предприятия.

Схема управления «предприятиемконгломератом», по существу совпадает, несмотря на наличие специализированного отдела со схемой управления качеством, ибо функции отдела управления качеством сводятся, в основном, к контрольной деятельности.

В 1924 году У. Шухарт предложил оптимизировать данный способ управления с помощью принципов теории статистической вариации, предоставив менеджерам статистическую контрольную карту. Улучшение работы не замедлило сказаться на результатах, однако дело ограничилось частичными переменами к лучшему. «Философия теории вариации» вместо применения ее в качестве базы для управления оказалась низведена до уровня статистических средств, используемых техническими специалистами с ограниченными и очень специализированными областями ответственности... Незнание теории поведения промышленных процессов делало руководство не способным правильно распознавать ситуации, требующие или не требующие действия. По этой причине руководство становилось чрезвычайно уязвимым к трем видам дорогостоящих ошибок менеджмента:

1) отношение ко всем вариациям выходных параметров процесса как к неожиданности в поведении и подавление, на самом деле, мнимых причин их, что ведет к дестабилизации процесса;

2) отношение ко всем вариациям выходных параметров процесса как к естественным проявлениям и бездействие по поводу обнаружения и подавления вызывающих их причин, что ведет к неустойчивому поведению;

3) предположение, что оптимизация и стабилизация процесса - это технические решения, за которые полностью отвечает конкретный отдел, a не решение организационной проблемы, требующее полной поддержки руководства и усилий нескольких отделов».

Перестройка управления предприятием на принципы системной организации обеспечивает:

взаимосвязь ключевых видов деятельности, чтобы различные отделы предприятий согласованно вовлекались в координацию действий, к примеру, по пересмотру качества продукции с учетом конкретных замечаний потребителей, совершенствованию обучения персонала, рекламные акции и т.п.;

встраивание иных процессов в ключевые виды деятельности;

интеграцию новых ключевых видов деятельности в существующие.

Опасное заблуждение при строительстве управления «предприятием - системой»состоит в толковании оптимальности как суммы оптимальных перестроек отдельных подразделений. В этом случае предприятие попрежнему рассматривается в качестве конгломерата, суммы отделов, играющих свою особую роль. Отсутствует взгляд на деятельность как интеграцию всех составляющих её.

В европейской литературе все чаще встречается новый термин «революция качества». Не будем рассуждать, насколько адекватно в нем схвачена динамика политики, направленной на совершенствование качества производства, отметим лишь то, что вовлечение в исследование понятия «революция» вполне выглядит естественно. Сравнение современной практики управления качеством с не столь отдаленным прошлым однозначно свидетельствует о радикальной перестройке понимания технологии 


\begin{tabular}{|c|c|c|c|c|c|c|}
\hline \multirow{4}{*}{ Impact Factor: } & ISRA (India) & $=3.117$ & SIS (USA) & $=0.912$ & ICV (Poland) & $=6.630$ \\
\hline & ISI (Dubai, UAE & $=0.829$ & РИНЦ (Russia & $=0.156$ & PIF (India) & $=1.940$ \\
\hline & GIF (Australia) & $=0.564$ & ESJI (KZ) & $=8.716$ & IBI (India) & $=4.260$ \\
\hline & JIF & $=1.500$ & SJIF (Morocco & $=5.667$ & OAJI (USA) & $=0.350$ \\
\hline
\end{tabular}

качества. В «революции качества» дифференцируют четыре этапа:

1960-е годы - этап самоопределения качества товаров как главного фактора рыночной конкуренции;

1970-е годы - сдвиг от доминанты качества товаров к качеству технологий и производства;

1980-е годы - переход от качества технологий и производства к качеству «системы качества» или «системы управления качеством»;

1990-е годы - восхождение к качеству образования, качеству интеллектуальных ресурсов.

Путь европейцев к Болонским договоренностям был долгим и непростым. Он обнажил многие недостатки и противоречия. В частности:

очевидность разрыва между требованиями общества промышленно развитых государств к существующей в них системе образования и её возможностям;

расхождение между тем, что наиболее значимые открытия и изобретения совершаются преимущественно на стыке наук, а образование строится на разделении предметов;

недостаточную мобильность организации переподготовки специалистов, её усиливающееся отставание от ускорения изменений в технике, технологии, науке;

инерцию в разработке новых образовательных парадигм, программ, методик, отставание в разработке новой учебной литературы.

Тем не менее, есть и серьезный прогресс выделены и сбалансированы три уровня обеспечения качества образования: вузовской, национальной и европейский.

Интеллектуализация экономики, усиленная превращением науки в непосредственную силу производства, о которых так любят говорить специалисты XXI века, обнажили фундаментальное противоречие человеческого сознания между умом и порядочностью. Философы искали его разрешение в разумности homo sapiens, подчеркивая базовую функцию нравственности. Гипертрофируя деятельность сознания за счет актуализации интеллектуальных способностей, акцентируя внимание к творческим силам ума, сводя сознание к мышлению, сторонники «умной» экономики не видят или не хотят видеть зависимость ума от нравственности, противопоставляют роль ума значению нравственных ценностей. Мы уже отмечали, что сила знаний только в частном масштабе может иметь свой собственный вектор. В системном выражении сила знаний направляется коренными, а не приватными и корпоративными интересами производителя. Нравственность сформировалась как первая производная труда в качестве способа сначала выживания, потом развития человечества. Основным критерием социального прогресса не может быть эффективность производства - это чисто экономический параметр. Человек существо общественное и степень его достижений определяется тем, насколько движение укрепляет человеческие отношения - в первую очередь - нравственные. Без жесткого нравственного регламента, подчиняющего себе все остальные стороны бытия человека, нет исторической перспективы.

Нынешний кризис показал уязвимость демократических отношений. Свободу действиям, приведшим к кризису, открыла аморфность демократических постулатов, не умное поклонение регулирующим способностям рынка, не адекватное восприятие действий «сильных мира сего». Инновации в экономическом строительстве выражают новое мышление человечества, сплавляющее интеллект и нравственность.

Первыми построят инновационную экономику китайцы и индусы, то есть те народы, которые сохранили в сознании авторитет нравственных ценностей, подчинив научнотехнические достижения национальным интересам. Именно они в ближайшем будущем «обуют» и европейцев, и американцев, и, повидимому, нас тоже!

Сто пятьдесят лет назад К. Маркс писал «В наше время все как бы чревато своей противоположностью ...Даже чистый свет науки не может, по-видимому, сиять иначе, как только на мрачном фоне невежества. Все наши открытия и весь наш прогресс как бы приводят к тому, что материальные силы наделяются интеллектуальной жизнью, а человеческая жизнь, лишенная своей интеллектуальной стороны, низводится до степени простой материальной силы. Этот антагонизм между современной промышленностью и наукой, с одной стороны, современной нищетой и упадком, с другой, этот антагонизм между производительными силами и общественными отношениями нашей эпохи есть осязаемый, неизбежный и неоспоримый факт».

Можно не разделять коммунистический вывод К. Маркса, но одно бесспорно - он абсолютно прав в оценке социально-экономической ситуации середины XIX века. Необходима была и остается перестройка в общественном сознании. Деньги не должны возвышаться над нравственностью, иначе разрушиться главная цитадель - homo sapiens его мудрость. Правомочность выводов К. Маркса подтверждается той социально-экономической ситуацией, которая сложилась сегодня в обувной промышленности России.

Либерализация внешнеэкономических отношений сыграла с нею роковую роль в 


\begin{tabular}{|c|c|c|c|c|c|c|}
\hline \multirow{4}{*}{ Impact Factor: } & ISRA (India) & $=3.117$ & SIS (USA) & $=0.912$ & ICV (Poland) & $=6.630$ \\
\hline & ISI (Dubai, UAE & $=0.829$ & РИНЦ (Russia & $=0.156$ & PIF (India) & $=1.940$ \\
\hline & GIF (Australia) & $=0.564$ & ESJI (KZ) & $=8.716$ & IBI (India) & $=4.260$ \\
\hline & JIF & $=1.500$ & SJIF (Morocco & $=5.667$ & OAJI (USA) & $=0.350$ \\
\hline
\end{tabular}

случившейся катастрофе. С одной стороны, хлынул поток более качественной импортной обуви, в результате чего российская обувь перестала пользоваться спросом. С другойвоспользовавшись правом ставить любые цены, наши производители подняли их до уровня цен на импортную обувь, а уровень качества остался прежним. И по этой причине ее тоже перестали покупать.

Правительству вмешаться бы, защитить своих товаропроизводителей (дешевыми кредитами и таможенными барьерами), но сделано это не было. В правительстве не помогали в силу сложившихся ошибочных убеждений: наш легпром неконкурентоспособен, поэтому дешевле обойдется, если обувь завести из-за границы. В общем, в правительстве посчитали легпром, как и сельское хозяйство, «черной дырой», недостойной инвестирования.

Когда мы слышим о защите российских производителей чего бы то ни было: станков и автомобилей, одежды и обуви, продовольствия и мебели и т.д., то всегда думаем о теневой стороне медали от таких нововведений: о качестве товаров. У обувных предприятий теряется стимул улучшать и обновлять ассортимент обуви, так как в отсутствие импорта люди будут брать что угодно. Но производители имеют в виду другое: декриминализацию поступления на отечественный рынок одежды и обуви.

Потребность российского рынка легкой промышленности общим объемом 1250 млрд рублей формируется за счёт следующих источников: 230 млрд рублей $(18,4 \%)-$ российские легальные производители; 240 млрд рублей $(19,2 \%)$ - легальный импорт; 780 млрд рублей $(62,4 \%)-$ незаконно ввезённый и произведенный контрафактный товар, такая же картина характерна и обувному рынку.

Сегодня население России приобретает порядка 600 млн. пар обуви, отечественная промышленность произвела лишь 52 млн. пар (в 2077 году - 46 млн пар), 100 млн пар поступает по официальному импорту. Откуда же берутся остальные четыреста с лишним миллионов? Ввозятся всевозможными незаконными путями, т.е. остается огромный объем обуви, который был бы востребованным, если бы отечественным обувным предприятиям оказывалась финансовая поддержка и правовая защита.

Почему нет отбоя от желающих вкладывать средства в нефтегазовую отрасль? Почему идут в Россию автомобильные компании? Почему даже в сельское хозяйство есть желающие инвестировать? И почему на фоне всех этих «почему» инвесторы не идут в лёгкую промышленность?
Общий ответ таков: нет благоприятных условий для инвесторов. Потому с созданием совместных предприятий в нефтегазовой и автомобильной отраслях всё нормально, потому что там за каждым предприятием следят министры и губернаторы. И уж тут чиновники побоятся брать взятки и не станут гонять инвесторов по бюрократическому кругу. А открытие предприятий легпрома, в силу их малых объёмов, целиком в руках чиновников. Кроме того, зарубежные фирмачи рассуждают: чего в России создавать предприятия, рисковать, когда там наши товары и так хорошо покупают? И идут российские и западные фирмы в Китай, где идеальные условия для инвестиций, где дешёвая, дисциплинированная рабочая сила, где стабильная благоприятная налоговая система ...

Сегодня оборудование на предприятиях легпрома чрезвычайно изношено. Коэффициент обновления в последние годы $0,4-0,6 \%$ в год. В то время как на иностранных предприятиях технологическое оборудование заменяется каждые 5-7 лет, то есть по 15-20\% ежегодно. Как тут конкурировать?[12-13]

Для технического перевооружения отрасли нужны средства. Они могут или зарабатываться самими предприятиями, или предоставляться в виде кредитов, или поступать от зарубежных инвесторов. Возможности самих предприятий весьма ограничены. Кредиты коммерческих банков дороги, правительство льготное кредитование не поощряет, зарубежные инвесторы в отрасль, как уже сказано, не идут.

Отсюда и ответ на вопрос, что делать? Воnepвыx, предоставлять предприятиям кредиты под минимальные проценты, а ещё лучше - без таковых (как хозяйствам, производящим продовольствие, по национальному проекту «Развитие АПК»). Bо-вторых, создать такие условия, чтобы в лёгкую промышленность пошли иностранные компании, привнося помимо капиталов свой дизайн, культуру производства, менеджмент и т. д.

Надо отметить, что последние двадцать лет показали: предприятия легпрома очень отзывчивы на малейшее внимание к ним властей, на изменение конъюнктуры. Взять хотя бы 1991 год, известный дефолтом. Подорожал импорт, и тут же ожила лёгкая промышленность. Три года был рост. Другой пример. Исключительно низкие экспортные пошлины на сырые шкуры привели к их массовому вывозу за рубеж. Кожевеннообувные фабрики оказались без сырья. В 2000 году была введена заградительная пошлина на вывоз кож до 500 евро за тонну (вместо 100 евро). В результате производство готовой кожи в России выросло с 1,1 до 2,2 млрд кв. дециметров. Вместо импорта кожтоваров начался их экспорт.

В пользу того, что реанимация лёгкой промышленности не только необходима, но и 


\begin{tabular}{|c|c|c|c|c|c|c|}
\hline \multirow{4}{*}{ Impact Factor: } & ISRA (India) & $=3.117$ & SIS (USA) & $=0.912$ & ICV (Poland) & $=6.630$ \\
\hline & ISI (Dubai, UAE & $=0.829$ & РИНЦ (Russia & $=0.156$ & PIF (India) & $=1.940$ \\
\hline & GIF (Australia) & $=0.564$ & ESJI (KZ) & $=8.716$ & IBI (India) & $=4.260$ \\
\hline & JIF & $=1.500$ & SJIF (Morocco & $=5.667$ & OAJI (USA) & $=0.350$ \\
\hline
\end{tabular}

возможна, говорят сегодня примеры успешной работы отдельных предприятий отрасли в ЮФО и СКФО, как старых, так и созданных вновь. Назовем хотя бы некоторые.

Новороссийская обувная фабрика «Бриз Босфор», предприятие создано на «голом месте», даёт 16 млн. пар обуви в год и вся обувь востребована.

Ростовское предприятие «Глория Джинс». Оно также новое, начиналось с кооператива. Даёт продукции на 7 млрд рублей (до $10 \%$ всех российских швейных товаров и до $30 \%-$ детских). Его изделия идут за рубеж, в том числе в США.

Так что стоит «Родине» подставить плечо и заработает её лёгкая промышленность, оказавшаяся в столь тяжёлом положении, особенно в ЮФО и СКФО.

$\mathrm{Mbl}$ уже не говорим о том, что возрождение легпрома помогло бы решить и сочиальные проблемы мальх городов ЮФО и СКФО, в которых проживают сегодня более 16 миллионов человек. Здесь с началом реформы первыми погибали мелкие фабрики (филиалы объединений). Но мелкими они представляются в масштабах страны, или отрасли. В то время как для райцентра в 10-20 тысяч населения какаянибудь обувная фабрика на 300 работающих это крупное, градообразующее предприятие, которое не только давало деньги в бюджет и выпускало нужные для населения товары, но и обеспечивало достойную жизнь многим жителям малого города или районного центра.

Вряд ли в этих городах когда-нибудь будут строиться автозаводы или филиалы оборонных заводов, а легпромовские - пожалуйста. Но пока, насколько нам известно, проблема в такой постановке правительством даже не обсуждается.

Не слышно озабоченности по поводу ещё одной проблемы, даже угрозы, возникшей в связи с развалом легпрома. Ранее на каждом предприятии лёгкой' промышленности, как и всякой другой, имелись мобилизационные резервы (оборудования, инструментов, материалов и т.д.), позволявшие в течение суток в случае начала войны перейти на выпуск необходимой армии продукции. Вместо модельной обуви шить кирзовые сапоги, вместо костюмов и пальто - гимнастёрки и шинели, вместо «модных дублёнок»- солдатские полушубки и т. п. Не дай Бог такое случится нам не во что будет одеть и обуть нашу армию, тем более что ЮФО приграничный округ с непростой ситуацией. Это ещё одна причина, по которой необходимо самым серьёзным образом заняться лёгкой промышленностью.

Весьма острая ситуация сложилась с обеспечением детской обувью. Большинство российских обувных предприятий продолжает сокращать выпуск детской обуви в связи с высоким ростом цен, обусловленным отменой дотаций из Федерального бюджета, а некоторые обувные фабрики, в том числе и в ЮФО и СКФО, вовсе прекратили выпуск. В 2018 году по сравнению с 2009 годом производство детской обуви прекратилось.

На потребительском рынке ЮФО и СКФО товаров для детей отечественных производителей активно вытеснили зарубежные поставщики, которые могут себе позволить передать на реализацию обувь с условием оплаты после ее фактической продажи. Однако, хлынувший на наши рынки из-за рубежа поток красивой и модной детской обуви, в большинстве своем не имеющей сертификатов соответствия, не говоря уже о гигиенических сертификатах, - это, с нашей точки зрения, преступление перед детьми.

Покупательский спрос выступает в качестве основного фактора, влияющего на формирование ассортимента, который в свою очередь направлен на максимальное расширение и удовлетворение спроса населения.

Покупательский спрос объединяет целую группу показателей, которые будут формировать свою нишу на обувь отечественную, а именно:

c учетом возрастных особенностей $u$ трудовой деятельности:

обувь для детей;

обувь для пожилых;

обувь для отдыха;

обувь специального назначения;

офисная обувь;

для социально незащчищенной группь людей:

обувь для безработных, получающих социальное пособие;

обувь для пенсионеров;

обувь для лиц, имеющих хронические заболевания;

учитыввая особенности регионов:

обувь национальная;

обувь эксклюзивная;

обувь элитная.

Таким образом, реализация требований основных параметров, формирующих покупательский спрос, позволит сформировать отличительные признаки, которым должен будет удовлетворять новый ассортимент обуви.

К параметрам, определяющим спрос, относятся:

сравнительные

конкурентные преимущества; продукт должен иметь ярко выраженные особенности, или ярко выраженные преимущества по сравнению с существующими на рынке аналогами, изделиями, или услугами конкурентов;

социальная ориентация; необходимо, чтобы продукт вписывался в существующие социальные условия, чтобы предлагаемое 


\begin{tabular}{|c|c|c|c|c|c|c|}
\hline \multirow{4}{*}{ Impact Factor: } & ISRA (India) & $=3.117$ & SIS (USA) & $=0.912$ & ICV (Poland) & $=6.630$ \\
\hline & ISI (Dubai, UAE & $=0.829$ & РИНЦ (Russia & $=0.156$ & PIF (India) & $=1.940$ \\
\hline & GIF (Australia) & $=0.564$ & ESJI (KZ) & $=8.716$ & IBI (India) & $=4.260$ \\
\hline & JIF & $=1.500$ & SJIF (Morocco & $=5.667$ & OAJI (USA) & $=0.350$ \\
\hline
\end{tabular}

изделие соответствовало сложившемуся стилю жизни и системе ценностей потребителя;

способность удовлетворить потребителя; продукт должен выполнять все функции для удовлетворения ключевых нужд и запросов покупателя.

Предлагается следующий комплекс мер: создание региональной программы развития и поддержания отечественных обувных производств на территории округа;

принятие мер по сокращению ввозимой импортной обуви в регион. Эти меры должны предусматривать прежде всего пресечение торговли обувью, ввезенной контрабандным путем и без разрешения на ее реализацию на местных рынках;

помощь в трудоустройстве молодых специалистов, выпускников вузов на имеющиеся и вновь создаваемые обувные предприятия;

помощь предприятиям в процессе продвижения отечественных обувных марок на местных рынках. Прежде всего, необходимо разработать грамотную маркетинговую стратегию для региональных обувных предприятий; создание

кредитования

$$
\text { специальной программы }
$$
предприятий легкой промышленности региона, учитывающей специфику производства: сезонный характер реализуемой продукции и особенность оборачиваемости оборотных средств предприятий отрасли.
На наш взгляд, для успешной реализации всех перечисленных мер, необходима заинтересованность как федеральных, так и региональных ветвей власти в организации и развитии обувного кластера, что спровоцирует снижение цен на комплектующие материалы, на энергозатраты и транспорт, обеспечивая производителю за счет ценовой ниши возможность предлагать отечественному потребителю востребованную и конкурентоспособную обувь. Все это в совокупности обеспечит такому формированию долгую жизнь и устойчивые позиции не только на внутренних, но, что особенно важно, и на зарубежных рынках. Нужна лишь добрая воля и заинтересованность всех участников по реализации предложенных мероприятий. Такие подвижки сделаны, требуется теперь твердая воля и желание заинтересованных сторон. Ассортимент для формирования потребительской ниши приведён на рис. 2 - 5

И вновь состояние качества отечественных товаров является главной базовой основой для успеха современных отечественных предприятий. Такой вывод имеет право на жизнь, потому что качество - древнейшая ценность человечества. И именно по качеству российских товаров, услуг, по качеству управления мы проигрываем в мировой конкуренции. Вы где-нибудь в мире видели сложные изделия с надписью made in Russia? Мы тоже не видели... 


\begin{tabular}{|c|c|c|c|c|c|c|}
\hline \multirow{4}{*}{ Impact Factor: } & ISRA (India) & $=3.117$ & SIS (USA) & $=0.912$ & ICV (Poland) & $=6.630$ \\
\hline & ISI (Dubai, UAE & $=0.829$ & РИНЦ (Russia) & $=0.156$ & PIF (India) & $=1.940$ \\
\hline & GIF (Australia) & $=0.564$ & ESJI (KZ) & $=8.716$ & IBI (India) & $=4.260$ \\
\hline & JIF & $=1.500$ & SJIF (Morocco) & $=5.667$ & OAJI (USA) & $=0.350$ \\
\hline
\end{tabular}

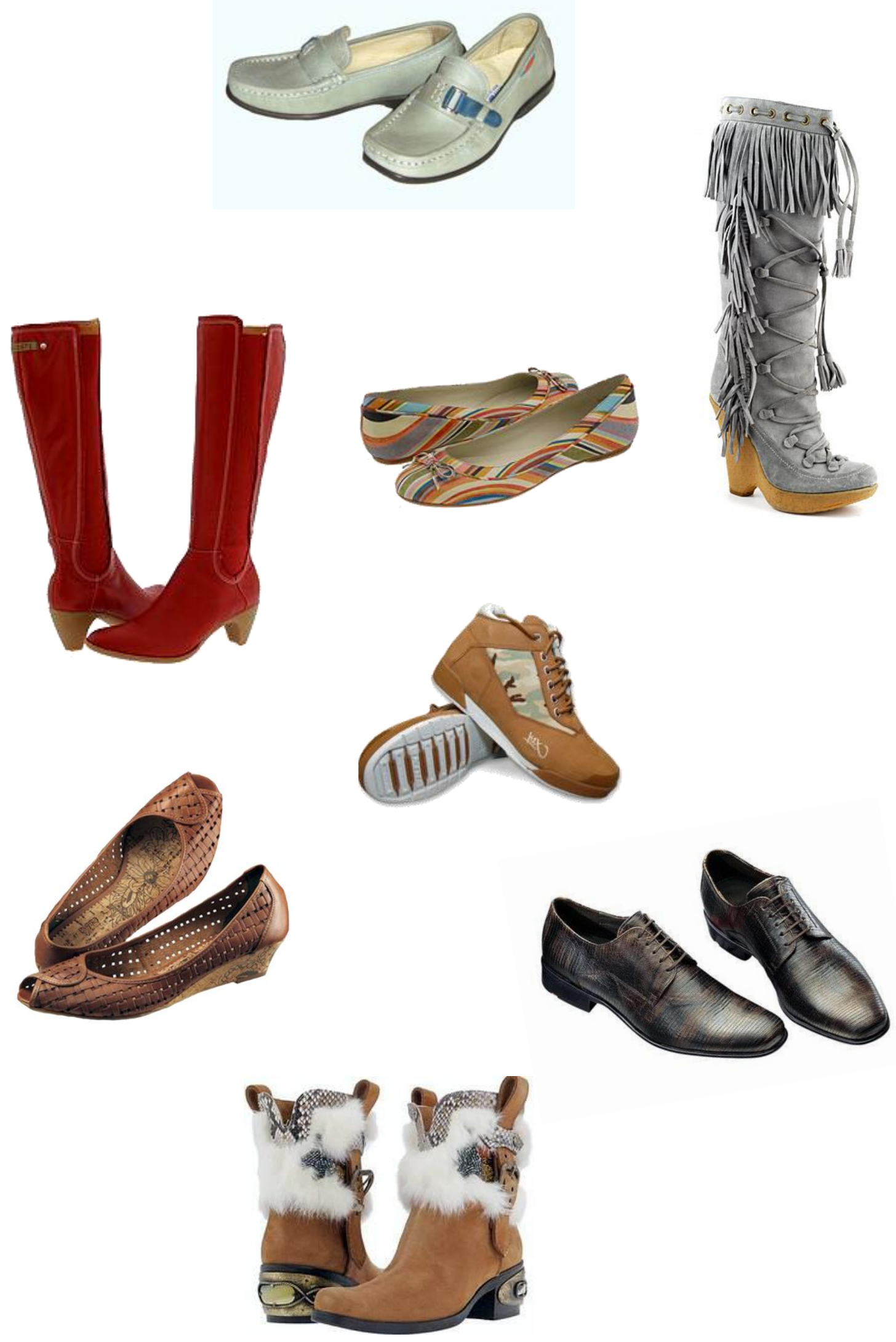

Рис. 6 Ассортимент для формирования потребительской ниши с учетом особенностей регионов. 


\begin{tabular}{llllll} 
& ISRA (India) $=\mathbf{3 . 1 1 7}$ & SIS (USA) $=\mathbf{0 . 9 1 2}$ & ICV (Poland) & $\mathbf{= 6 . 6 3 0}$ \\
Impact Factor: & ISI (Dubai, UAE) $=\mathbf{0 . 8 2 9}$ & PUHЦ (Russia) $=\mathbf{0 . 1 5 6}$ & PIF (India) & $=\mathbf{1 . 9 4 0}$ \\
& GIF (Australia) $=\mathbf{0 . 5 6 4}$ & ESJI (KZ) $=\mathbf{8 . 7 1 6}$ & IBI (India) & $\mathbf{4 . 2 6 0}$ \\
& JIF & $\mathbf{1 . 5 0 0}$ & SJIF (Morocco) $=\mathbf{5 . 6 6 7}$ & OAJI (USA) & $\mathbf{0 . 3 5 0}$ \\
\hline
\end{tabular}

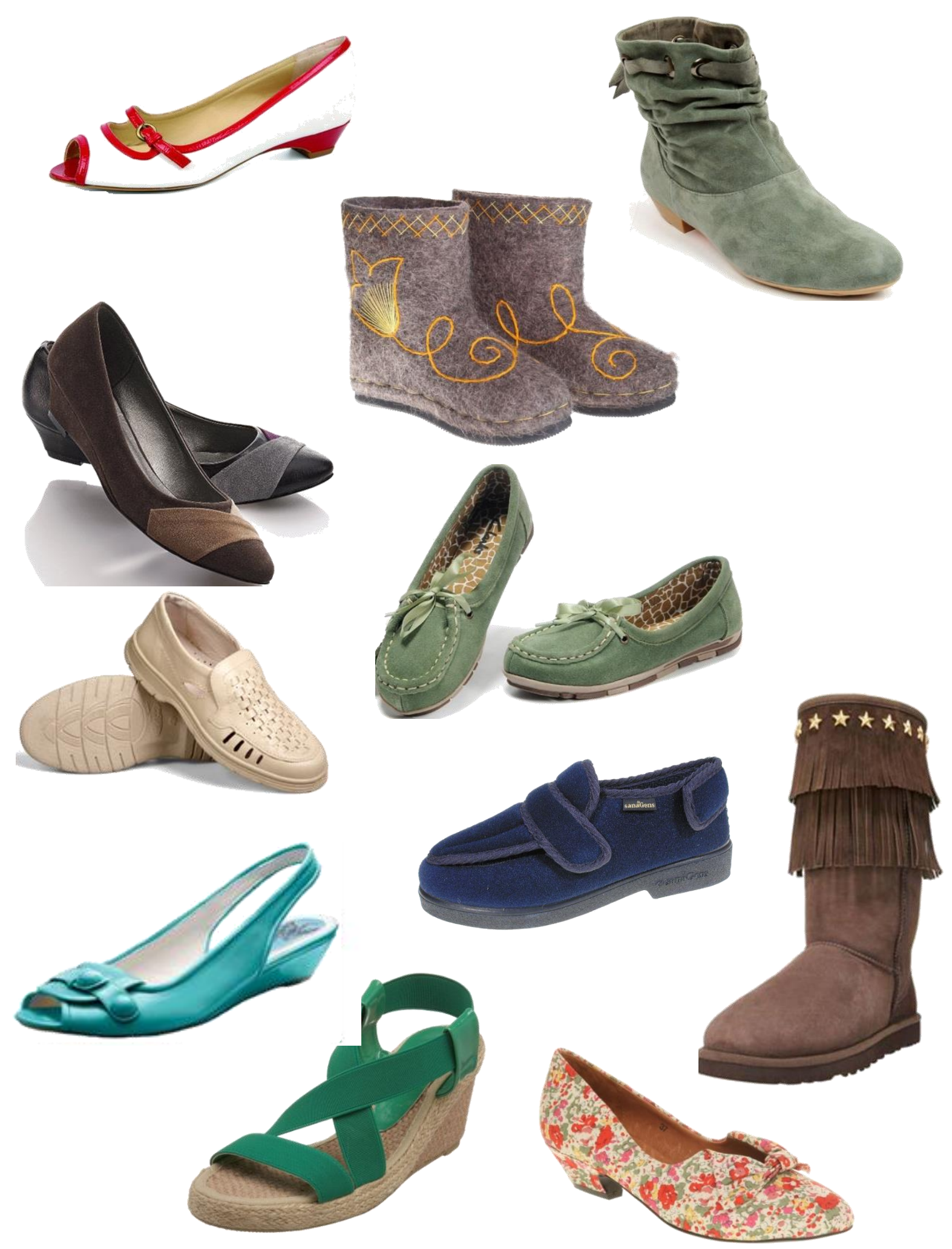

Рис. 7 .( Ассортимент обуви для пожилых). 


\begin{tabular}{|c|c|c|c|c|c|c|}
\hline \multirow{4}{*}{ Impact Factor: } & ISRA (India) & $=3.117$ & SIS (USA) & $=0.912$ & ICV (Poland) & $=6.630$ \\
\hline & ISI (Dubai, UAE & $=0.829$ & РИНЦ (Russia) & $=0.156$ & PIF (India) & $=1.940$ \\
\hline & GIF (Australia) & $=0.564$ & ESJI (KZ) & $=8.716$ & IBI (India) & $=4.260$ \\
\hline & JIF & $=1.500$ & SJIF (Morocco) & $=5.667$ & OAJI (USA) & $=0.350$ \\
\hline
\end{tabular}

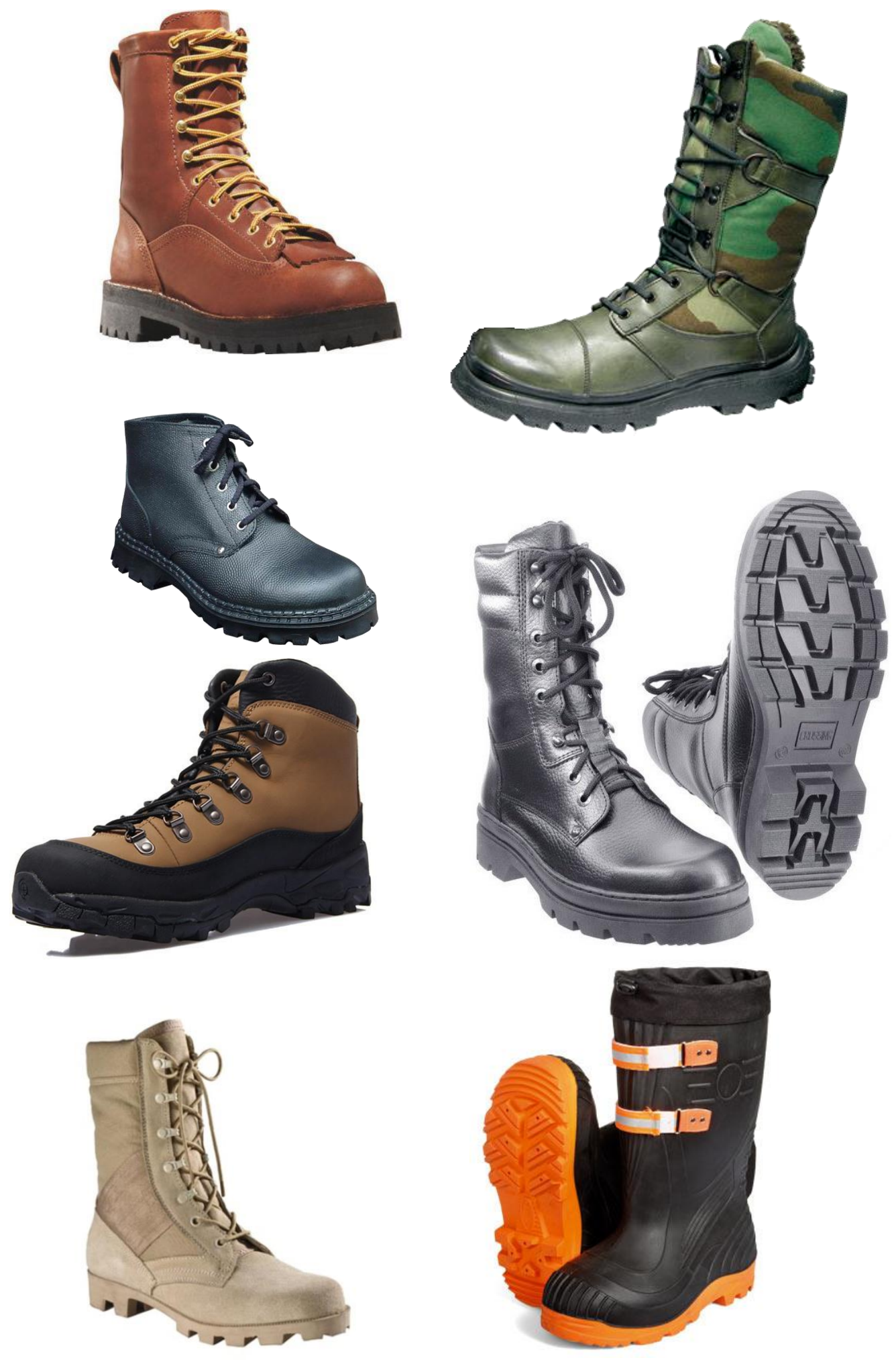

Рис.8 (Ассортимент мужской рабочей обуви и обуви для военных). 


\begin{tabular}{|c|c|c|c|c|c|c|}
\hline \multirow{4}{*}{ Impact Factor: } & ISRA (India) & $=3.117$ & SIS (USA) & $=0.912$ & ICV (Poland) & $=6.630$ \\
\hline & ISI (Dubai, UAE & $=0.829$ & РИНЦ (Russia) & $=0.156$ & PIF (India) & $=1.940$ \\
\hline & GIF (Australia) & $=0.564$ & ESJI (KZ) & $=8.716$ & IBI (India) & $=4.260$ \\
\hline & JIF & $=1.500$ & SJIF (Morocco) & $=5.667$ & OAJI (USA) & $=0.350$ \\
\hline
\end{tabular}

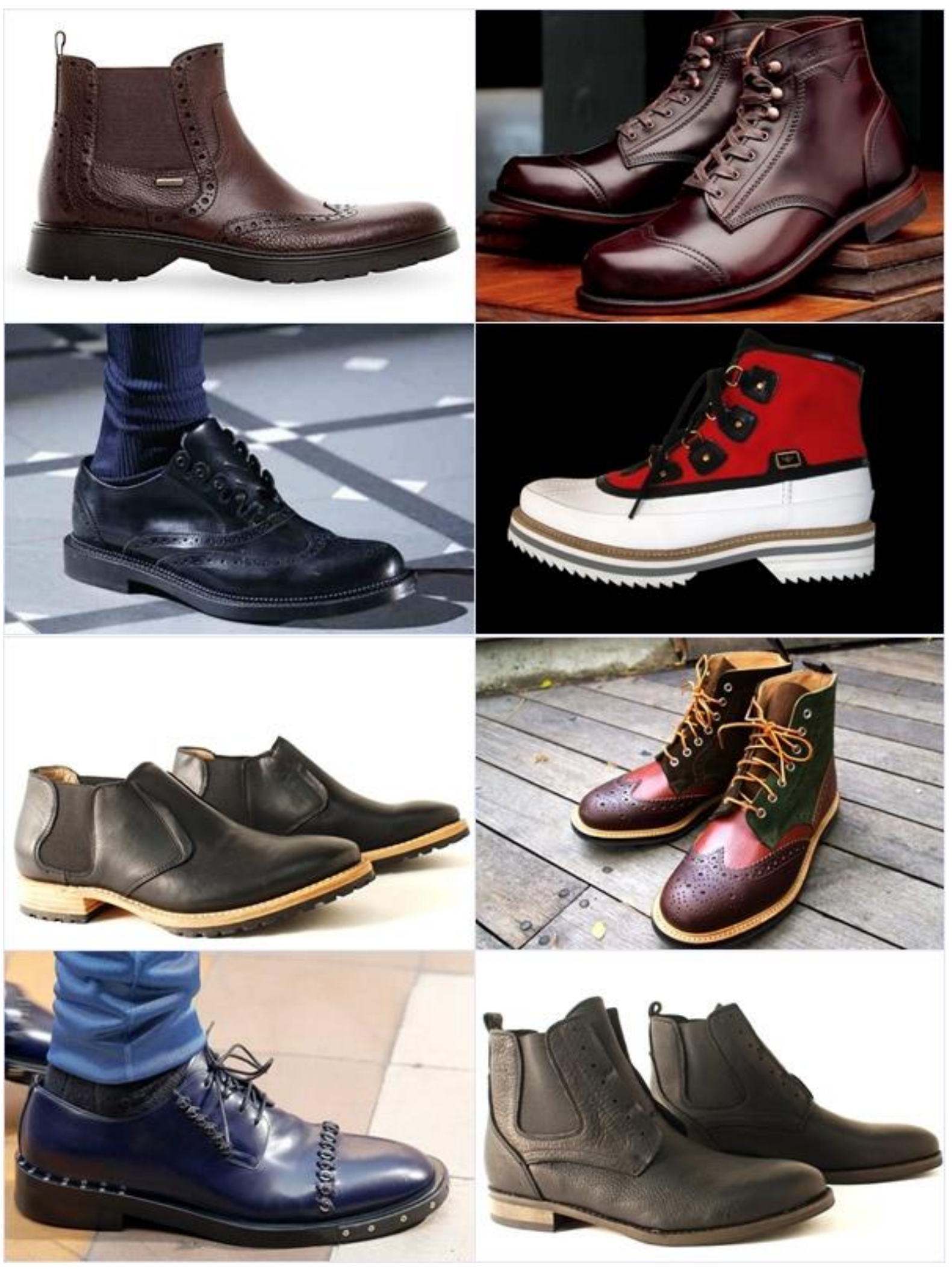

Рис. 9 Элитный ассортимент мужской обуви. 


\begin{tabular}{|c|c|c|c|c|c|c|}
\hline \multirow{4}{*}{ Impact Factor: } & ISRA (India) & $=3.117$ & SIS (USA) & $=0.912$ & ICV (Poland) & $=6.630$ \\
\hline & ISI (Dubai, UAE & $=0.829$ & РИНЦ (Russia & $=0.156$ & PIF (India) & $=1.940$ \\
\hline & GIF (Australia) & $=0.564$ & ESJI (KZ) & $=8.716$ & IBI (India) & $=4.260$ \\
\hline & JIF & $=1.500$ & SJIF (Morocco & $=5.667$ & OAJI (USA) & $=0.350$ \\
\hline
\end{tabular}

Долго надеялись на всемирную систему ISO. Увы, в российских условиях она скатилась в кризис. Извините, уважаемые коллеги из мира сертификации качества, но пора публично перечислить то, во что она превратилась и что между собой признают едва ли не все: [15-16]

- необъятное число документов, ориентироваться в которых нет сил;

- бессмысленность многих из них (к примеру, по условиям ISO требуются должностные инструкции, и все кидаются на ходу что-то набрасывать, а потом забывают их без следа);

- один предприниматель как-то сказал: «Мы прошли сертификацию по ISO». И тут же добавил: «Не подумайте, нас сертифицировала такая-то норвежская компания». Догадываетесь, о чем речь? Да, продажа сертификатов. Не все, конечно, продают, но репутация случайной не бывает.

Договоримся о терминах. Качество - это что? Соответствие стандартам, ответит большинство. Конечно, там, где стандарты возможны, это так. Хотя у стандартов есть допуски. И разница между верхним и нижним делениями в этих допусках бывает значительная. А есть и границы стандартизации. Скажем, контакт с клиентом. Все знают, что качество такого контакта критически важно для успеха бизнеса, когда цены, ассортимент, сроки выравниваются под прессом конкуренции. Можно считать стандартом определенный набор приветливых слов, дресс-код и т. п. Хотя мы хорошо знаем, что ими прикрыто.

Нынешнее увлечение описаниями бизнеспроцессов тоже постепенно приближается к абсурду. А где-то уже и достигло его: на разных фирмах мы встречаем уже жесткое описание собеседования не только при приеме на работу, но даже стандарт на совещание и на ведение переговоров.

Теперь появляется другой подход: качество - это соответствие потребностям клиента, пользователя. Кто покупает, тот и оценивает. Нужно только поточнее понять, что именно он ценит. Если попали - вот оно, требуемое качество, т. е. степень удовлетворенности потребителя свойствами товара [9].

Но и этот подход ограничен и тянется из прошлого века. Тогда бесспорной считалась формула: покупатель всегда прав. В наше время куда вернее другой императив: покупатель не знает наших возможностей.

К чему мы ведем? Понимание качества как соответствия (стандарту, потребности) устаревает. Сегодня гораздо более емким становится понимание его как сравнение с другим продуктом или с тем же, но прежним. Сравнение дает превосходство продукта над продуктом, услуги над услугой, специалиста над специалистом, организации над, организацией. Сравнение же со стандартом или потребностью не предполагает превосходства. Там возможно лишь равенство. Стандарт и потребность указывают на минимум. А кому достаточно минимума? Немногим. Зато превосходство интересно всем, потому что закон возрастания потребностей неумолим.

Практически это означает переключение системы оценки качества на уровни. Например:

А. Достаточное качество, ниже которого идет дефект, т. е. минимум допустимого, использование которого не нанесет ущерба.

Б. Эталонное качество - по принципу соответствия эталону, т. е. лучшему из имеющегося. Эталон может появиться из стандарта, но им может служить любой образец: из того, что вживую имеем в своей компании, у конкурентов или хотя бы где-то в известном нам виде.

В. Авангардное качество - то, что достигнуто впервые, превосходит эталоны, но может рассчитывать на платежеспособный спрос и выход на рентабельность сразу или в перспективе.

Вот такая вертикаль качества, возможно, допускается и большее количество степеней. И еще: пора отказаться от мысли, что любое качество можно измерить. Оценить можно все, но измерению поддается немногое из того, что для нас важно.

На рис.6 представлена модель комплексного процесса управления качеством продукции и услуг, производимых как в отдельно взятых регионах, так и в обувной отрасли в целом. [1820]

$\begin{array}{llr}\text { Модель } & \text { представляет } & \text { собой замкнутую } \\ \text { систему } & \text { управления } & \text { (регулирования) }\end{array}$ реализующую принцип регулирования «по отклонению». Качество продукции на потребительском рынке можно охарактеризовать многомерным показателем качества $Q$. В процессе подтверждения соответствия, проведения испытаний и сертификации продукции формируется документированный показатель качества продукции $Q_{d}$. Требуемый высокий показатель качества $Q_{0}$ задается в технической документации на лучшие мировые образцы, в технических регламентах, национальных ГОСТ и международных ИСО стандартах. В процессе сравнения этих двух величин, проводимого конкурсной комиссией, определяется отклонение фактического показателя качества от заданного:

$$
\Delta Q=Q_{0}-Q_{d}
$$




\begin{tabular}{llllll} 
& ISRA (India) $=\mathbf{3 . 1 1 7}$ & SIS (USA) $=\mathbf{0 . 9 1 2}$ & ICV (Poland) & $\mathbf{= 6 . 6 3 0}$ \\
Impact Factor: & ISI (Dubai, UAE) $=\mathbf{0 . 8 2 9}$ & PUHL (Russia) $=\mathbf{0 . 1 5 6}$ & PIF (India) & $=\mathbf{1 . 9 4 0}$ \\
& GIF (Australia) $=\mathbf{0 . 5 6 4}$ & ESJI (KZ) $=\mathbf{8 . 7 1 6}$ & IBI (India) & $\mathbf{4 . 2 6 0}$ \\
& JIF & $\mathbf{1 . 5 0 0}$ & SJIF (Morocco) $=\mathbf{5 . 6 6 7}$ & OAJI (USA) & $\mathbf{0 . 3 5 0}$ \\
\hline
\end{tabular}

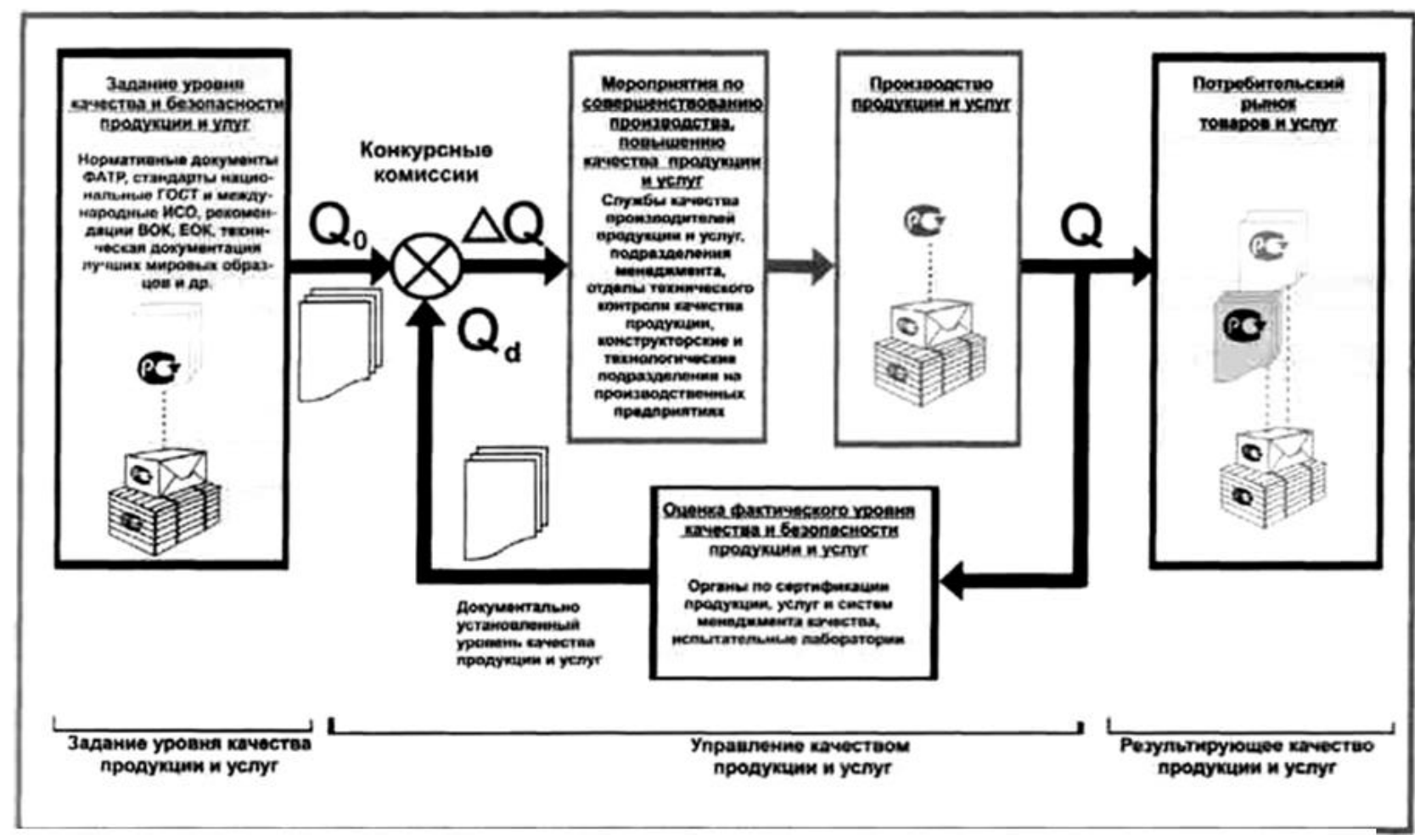

Рис 10- модель комплексного процесса управления качеством продукции и услуг в регионе.

Это отклонение $\Delta Q$ (рассогласование в системах регулирования) в нашем случае всегда неотрицательно ( $\Delta Q \geq 0$ ), поскольку правильно выбранный заданный высокий уровень $Q_{0}$ всегда выше фактического $Q_{d}$ или равен ему, что практически крайне редко. В таком случае мы имеем систему с ненулевой статической ошибкой, что наиболее характерно для статических систем с присущими им устойчивостью и быстродействием, точность которых определяется главным образом коэффициентом усиления и мощностью «пропорционального» регулятора. В нашем случае функцию регулятора выполняет звено «Мероприятия по обеспечению заданного уровня качества продукции и услуг», моделирующее систему менеджмента качества предприятия, службу качества на производстве, действия которых учитывают оценку качества продукции и рекомендации конкурсной комиссии [6].

Как видно из рис. 3 , качество $Q$ производимой и поставляемой на рынок продукции формируется в процессе ее производства в результате мероприятий по совершенствованию производства, повышению качества продукции и услуг, проводимых службой качества и подразделениями менеджмента качества, целенаправленные действия которых в свою очередь определяются результатами оценки продукции в процессе ее реализации.

В новых условиях хозяйствования прогрессивным является только такое производство, которое активно и динамично реагирует на возникающие проблемы. Принцип «производить только то, что нужно, тогда, когда нужно, и столько, сколько нужно», требует адаптации обувных предприятий к условиям выпуска продукции небольшими партиями с частым изменением ассортимента обуви, т.е. к условиям много ассортиментного мелкосерийного производства. Эффективность деятельности обувного предприятия, а во многом и способность к выживанию в конкурентной борьбе, зависят от способности в короткие сроки и с минимальными затратами перестраиваться на выпуск обуви соответственно колебаниям спроса. Большие 


\begin{tabular}{|c|c|c|c|c|c|c|}
\hline \multirow{4}{*}{ Impact Factor: } & ISRA (India) & $=3.117$ & SIS (USA) & $=0.912$ & ICV (Poland) & $=6.630$ \\
\hline & ISI (Dubai, UAE & $=0.829$ & РИНЦ (Russia) & $=0.156$ & PIF (India) & $=1.940$ \\
\hline & GIF (Australia) & $=0.564$ & ESJI (KZ) & $=8.716$ & IBI (India) & $=4.260$ \\
\hline & JIF & $=1.500$ & SJIF (Morocco) & $=5.667$ & OAJI (USA) & $=0.350$ \\
\hline
\end{tabular}

возможности для этого открывает разработка и внедрение гибких производственных систем.

Технологическая и организационная гибкость производственных систем определяет вариативный потенциал предприятий, их способность оперативно и адекватно реагировать на изменения рыночной конъюнктуры и выступает как механизм оптимизации структуры технологической системы с целью снижения себестоимости обуви. Таким образом, разработка гибких технологических процессов производства изделий из кожи обеспечивает высокую эффективность при много ассортиментном выпуске обуви и спровоцирует резкое увеличение спроса на продукцию обувных предприятий ЮФО и СКФО. Такие же проблемы характерны и для других отраслей легкой промышленности.[21-22]

\section{Заключение}

Одной из задач в системе повышения конкурентоспособности региона - выявить потенциал кластеризации региона. Традиции обувной отрасли в регионах ЮФО, СКФО и тенденции ее развития дают шанс на успех в случае взаимодействия всех участников процесса поставщиков, производителей, представителей власти, торговых и сервисных компаний. Первый шаг на пути к такому взаимодействию необходимо сделать в ходе обмена мнений и разъяснения взаимных позиций. Однозначно воспринимают ли участники обувного рынка области те проблемы, которые перед ними стоят? Каков вектор структурных изменений на российском кожевеннообувном рынке - к развитию или стагнации отрасли? Каковы условия и реальные возможности для развития конкурентоспособного производства в регионе? Какой должны быть поддержка власти на федеральном и региональном уровне? Можно ли в современных условиях делать ставку на взаимодействие и сотрудничество как на реальный фактор конкурентоспособности? Как решить проблему подготовки и закрепления кадров на производстве?

Для обувного бизнеса тема формирования регионального кластера весьма актуальна. Создание кластеров - один из самых эффективных инструментов повышения конкурентоспособности территорий. Необходимость кластерного подхода к управлению конкурентоспособностью предприятий, который состоит в разработке новой промышленной политики стимулирования организации и развития кластеров на основе формирования отношений сетевого сотрудничества и государственно-частного партнерства (кластерной политики) и включает исследование кластеров, кластерную стратегию и методы ее обеспечения являются палочкой выручалочкой на сегодня. С точки зрения прочесса управления кластерный подход рассматривается как совокупность этапов и мероприятий по организации кластеров и их развитию, т.е. кластеризации. Такой подход позволит малым и средним предприятиям легкой промышленности успешно конкурировать не только на внутреннем, но и на международном рынке.

Роль региональной и местной власти в запуске и координации кластерных проектов очень важна, в связи с этим удалось сформировать эффективный механизм представления интересов бизнеса во взаимоотношениях с властью. Предложен элемент, выполняющий функцию «координатора и коммуникатора». Для развития этого элемента нужен предметный диалог, основанный на взаимном доверии и заинтересованности, прежде всего, между самими субъектами отрасли,- в этом заинтересованы и власть, и бизнес. Необходимо разработать совместные предложения по направлениям, формам и методам государственной поддержки развития отраслевого кластера, а именно:

осуществление нового строительства, расширения и реконструкции производственных мощностей, объектов жилищного, социальнокультурного назначения, коммунального хозяйства и бытового обслуживания населения, административного управления, министерства чрезвычайных ситуаций, охраны окружающей среды и экологической безопасности на региональном уровне; [23-24]

$$
\text { содействие в }
$$

конкурентоспособности промышленных предприятий и ее продвижении на внутреннем и внешнем рынке;

организация и осуществление проектов в области производства программных средств;

обновление материально-технической базы производств кластера, внедрение новых технологий;

сохранение и развитие накопленного потенциала в сфере науки и научного обслуживания; совершенствование механизмов финансирования науки; реализация научных результатов в производственной и социальной сфере региона;

достижение качества образования, соответствующего государственному образовательному стандарту; осуществление регионального заказа на предоставление услуг дополнительного образования; достижение динамичного баланса между рынком труда и подготовкой профессиональных кадров; развитие высшего и среднего профессионального образования.

Предложен комплекс мер по антикризисному управлению легкой 


\begin{tabular}{|c|c|c|c|c|c|c|}
\hline \multirow{4}{*}{ Impact Factor: } & ISRA (India) & $=3.117$ & SIS (USA) & $=0.912$ & ICV (Poland) & $=6.630$ \\
\hline & ISI (Dubai, UAE & $=0.829$ & РИНЦ (Russia & $=0.156$ & PIF (India) & $=1.940$ \\
\hline & GIF (Australia) & $=0.564$ & ESJI (KZ) & $=8.716$ & IBI (India) & $=4.260$ \\
\hline & JIF & $=1.500$ & SJIF (Morocco & $=5.667$ & OAJI (USA) & $=0.350$ \\
\hline
\end{tabular}

промышленностью, включая следующие приоритетные направления:

повышение конкурентоспособности предприятий легкой промышленности;

развитие отраслевых информационных услуг; продолжение модернизации основных фондов;

смягчение недостатка оборотных средств; повышение

эффективности

государственного управления;

расшивка неплатежей.

Сформирован план мероприятий по реализации антикризисной программы в легкой промышленности, включая:

нормативно-правовое и научно-

методическое обеспечение антикризисной

деятельности;

развитие антикризисной инфраструктуры

поддержки предприятий легкой

промышленности;

расширение деловых возможностей

предприятий легкой промышленности;

финансовые механизмы поддержки и развития антикризисной деятельности предприятий легкой промышленности;

развитие межрегионального и международного сотрудничества предприятий легкой промышленности в антикризисной сфере.

Для дальнейшего совершенствования нормативно-правового регулирования антикризисной деятельности представляется целесообразным формирование плана мероприятий по реализации антикризисной программы в легкой промышленности, а именно:

конкретизация и детализация целей устойчивого развития предприятий легкой промышленности должна быть построена в рамках линии развития промышленного сектора экономики, которая базируется на структурных преобразованиях экономики и внедрении антикризисных технологий развития производства и экспорта товаров народного потребления. В рамках развития можно выделить три этапа, сроки которых представлены достаточно условно и могут быть скорректированы в процессе реализации устойчивого развития предприятий легкой промышленности:

2009-2012 гг. - Антикризисное развитие, предусматривающее преодоление кризисных явлений и восстановление кризисных потерь предприятий легкой промышленности и изыскание ресурсов для последующей модернизационной трансформации легкой промышленности

2013-2015 гг. - Инвестиционное обновление основных средств предприятий легкой промышленности, в том числе качественное повышение конкурентоспособности.
2016-2020 гг.- Инновационное развитие начало массового освоения новых видов оборудования и технологий, переход к экспансии на зарубежные рынки товаров легкой промышленности.

Использование разработанных и предлагаемых методических положений по повышению конкурентоспособности региона на основе теории кластера позволит принимать решение о привлечении и рациональном размещении инвестиционных средств, направленных на реализацию необходимых мероприятий по повышению эффективности деятельности субъектов привлекательного кластера и росту их конкурентоспособности.

Для решения поставленной задачи предложен конкурентоспособный ассортимент мужской, женской и детской обуви с учетом факторов, влияющих на потребительский спрос: соответствие основным тенденциям моды с учетом экономических, социальных и климатических особенностей регионов ЮФО и СКФО. В рамках разработанной стратегии будет организовано

конкурентоспособной производство использованием современных механизированных инновационных техпроцессов. Кроме того, будет предусмотрено производство обуви для удовлетворения спроса элитного потребителя с использованием большей доли ручного труда, чтобы придать обуви целевую направленность и высокую востребованность.

Для реализации разработанного ассортимента мужской, женской и детской обуви предложены инновационные технологические процессы её производства с использованием современного технологического оборудования на базе передовых нанотехнологий, формирующие основу для снижения затрат на обувь и, тем самым, повышающие ее конкурентоспособность в сравнении с аналогичным ассортиментом обуви ведущих мировых фирм, с возможностью широкоассортиментного выпуска обуви не только по видам, но и по методам крепления, что придаст ей востребованность и повышенную конкурентоспособность .Предложены компоновки технологического оборудования, которые представляют возможность формировать технологический процесс как для производства мужской, так и детской обуви в объемах, которые определяются имеющимися у регионов производственными площадями и используемыми формами организации производства, но конечно с учетом спроса для обеспечения её реализации в полном объеме[]2526.

При этом финансовое благополучие и устойчивость вновь создаваемых предприятий в регионах ЮФО и СКФО во многом зависит от 


\begin{tabular}{|c|c|c|c|c|c|c|}
\hline \multirow{4}{*}{ Impact Factor: } & ISRA (India) & $=3.117$ & SIS (USA) & $=0.912$ & ICV (Poland) & $=6.630$ \\
\hline & ISI (Dubai, UAE & $=0.829$ & РИНЦ (Russia) & $=0.156$ & PIF (India) & $=1.940$ \\
\hline & GIF (Australia) & $=0.564$ & ESJI (KZ) & $=8.716$ & IBI (India) & $=4.260$ \\
\hline & JIF & $=1.500$ & SJIF (Morocco) & $=5.667$ & OAJI (USA) & $=0.350$ \\
\hline
\end{tabular}

притока денежных средств, обеспечивающих покрытие взятых ими обязательств. Отсутствие минимально-необходимого запаса денежных средств может спровоцировать для предприятий финансовые затруднения. В свою очередь и избыток денежных средств может быть знаком того, что предприятие терпит убытки. Причина этих убытков может быть связана как с инфляцией и обесцениванием денег, так и с упущенной возможностью их выгодного размещения и получения дополнительного дохода. В любом случае именно постоянный анализ денежных потоков позволит предприятию контролировать свое реальное финансовое состояние и предупреждать от банкротства.

Денежные потоки от финансовой деятельности в большой степени формируются при выработке схемы финансирования и в процессе расчета эффективности инвестиционного проекта.

Если изготовленная обувь будет реализована не полностью, предприятие теряет часть прибыли, которая необходима для дальнейшего развития производства. Для снижения убытков производитель должен иметь ежедневные сведения о реализации продукции и принимать эффективные решения, а именно: или своевременно изменять цены на изготавливаемый ассортимент обуви, или же, что более эффективно и оправданно, приступать к производству нового, более востребованного на рынке ассортимента обуви.

Менеджеры по продажам или маркетологи, контролирующие процесс продажи конкретно выпускаемого ассортимента обуви, ежедневно должны рассчитывать поступление денежных средств от своей операционной деятельности. В результате отслеживания за поступлением денежных средств будем иметь информацию об их чистом притоке от своей операционной деятельности. Уменьшение объема продаж приведет к снижению денежного потока и потребует снижение отпускной цены изделия с целью повышения объема продаж. Если такое мероприятие не приводит к увеличению денежного потока, то необходимо принимать своевременное решение о целесообразности дальнейшего выпуска этого ассортимента обуви.

Для данного расчета важным является дифференциация данных, участвующих в расчете. Для расчета себестоимости конкретной выпускаемой модели исходными данными являются постоянные и переменные затраты, которые зависят от производственного оборудования, состава основных и вспомогательных материалов, численности работников и др.

Основными исходными данными, которые используются в процессе мониторинга, являются отпускная цена единицы продукции и объем продаж.

Таким образом, расчет может выполняться ежедневно или в выбираемом временном диапазоне, при этом, задавая только объем продаж и цену единицы изделия за определенный период, будем получать приращение денежного потока за этот период.

Расчеты проводятся на основе оценки степени выполнения и динамики производства и реализации продукции, определении влияния факторов на изменение величины этих показателей, выявлении внутрихозяйственных резервов и разработке мероприятий по их снижению, которые должны быть направлены на ускорение оборачиваемости продукции и уменьшение потерь, что позволит достичь значительного экономического эффекта.

Большое значение в управлении выпуском продукции имеет оценка фактического выпуска и реализации в пределах производственной мощности, то есть в границах «минимальный максимальный» объем производства. Сопоставление с минимальным, безубыточным объемом позволяет определить степень, или зону «безопасности» организации и при отрицательном значении «безопасности» снять с производства отдельные виды продукции, изменить условия производства и тем самым снизить расходы или прекратить производство данной продукции.

Сравнение достигнутого объема выпуска с максимальным объемом, определяемым производственным потенциалом организации, позволяет оценить возможности роста прибыли при увеличении объемов производства, если увеличится спрос или доля объема реализации обуви на рынке.

Для обувного предприятия, стремящегося к прочному положению на рынке, установление цены обуви для реализации имеет ключевое значение для успеха избранной стратегии. Цена является инструментом стимулирования спроса и одновременно представляет собой главный фактор долгосрочной рентабельности его деятельности.

В связи с этим необходимо проводить анализ безубыточности.

Рассмотрены различные соотношения объемов реализации и цен на выпускаемую продукцию. Снижение цен происходит, когда предприятие в целях увеличения объемов продаж использует систему скидок. Данное мероприятие приводит к увеличению выручки от реализации и получению дополнительной прибыли. Однако область дохода не является неограниченной - при достижении некоторого объема производства дальнейшее его расширение становится экономически невыгодным. 


\begin{tabular}{|c|c|c|c|c|c|c|}
\hline \multirow{4}{*}{ Impact Factor: } & ISRA (India) & $=3.117$ & SIS (USA) & $=0.912$ & ICV (Poland) & $=6.630$ \\
\hline & ISI (Dubai, UAE & $=0.829$ & РИНЦ (Russia & $=0.156$ & PIF (India) & $=1.940$ \\
\hline & GIF (Australia) & $=0.564$ & ESJI (KZ) & $=8.716$ & IBI (India) & $=4.260$ \\
\hline & JIF & $=1.500$ & SJIF (Morocco & $=5.667$ & OAJI (USA) & $=0.350$ \\
\hline
\end{tabular}

Эффективность всех этих мероприятий при создании кластера возможна лишь при активном взаимодействии ветвей власти и обязательно при поддержке на федеральном уровне- ЮФО и СКФО могут полностью или частично разгрузить обувщиков от инфраструктурных затрат при создании новых производств в рамках кластера. А решить вопросы налоговых преференций может только федерация; закрыть границы для серого и чёрного импорта - опять компетенция Москвы, учитывая что отрасль находится в тяжелом депрессивном состоянии, что для изменений в лучшую сторону нужен очень мощный набор инструментов и властные решения и совместные действия всех заинтересованных сторон.

Быть может, сейчас, когда донские обувщики видят, насколько быстро их ряды редеют под давлением конкуренции, готовность к совместным действиям будет выше. В противном случае Ростов уже очень скоро перестанет быть обувной столицей юга России. Наконец, институционально-организаџионный сценарий предполагает ответ на вопрос, как должен быть организован кластер, как он должен формироваться и выращиваться? Для нас кластер предполагает соорганизацию как минимум четырёх крупных технологических групп, которые образуют технологическую основу кластера:[27]

прорывные научные лаборатории - опытные производства, на которых создаются основы новых технологий;

разработческие центры, на базе которых будут создаваться макеты и образцы технологий для опробывания на экспериментальных производствах;

промышленно-технологические группы, способные осуществлять оснастку производства для изготовления опытных серий;

маркетинговые группы, способные продвигать новый тип продукции на рынок и формировать устойчивых спрос.

Управленческой надстройкой, обеспечивающей взаимосвязь этих четырех крупных технологических групп друг с другом, могут быть:

Совет инвесторов, который принимает решение о приоритетном финансирования того или иного проекта;

экспертный Совет, рассматривающий различные проекты по мере их подготовки к реализации;

креативный цеентр, подготавливающий материалы для принятия решений экспертным советом и советом инвесторов.

Достижение цели в области развития кластеров возможно только при проведении комплексной технологической модернизации реального сектора экономики региона.
Применительно к ЮФО и СКФО она возможна только при учете интересов всех участвующих хозяйствующих субъектов. Речь идет о таких направлениях, как:

увеличение доли инновационного сектора и внедрение технологических инноваций на предприятиях, образующих кластеры;

развитие предпринимательской деятельности в области крупного, среднего и малого бизнеса и взаимное сотрудничество в целях внедрения инноваций, что ведет к расширению действующих и созданию новых кластеров;

усиление связей и взаимозависимости предприятий промышленности и научноисследовательских и образовательных центров и школ;

совершенствование территориального размещения промышленных предприятий.

В заключение рассмотрения процесса формирования и реализации кластерной политики в регионе укажем, что это - сложная задача, разработка и реализация которой должна носить научный характер. Ее успех зависит от множества факторов и условий, и центральное место здесь принадлежит научным принципам управления и стремлению к динамичному развитию региона, заинтересованности всех ветвей власти, как муниципальных и региональных, так и федеральных ветвей власти.

Тем не менее, наиболее слабым местом предприятий является низкий уровень информационного обеспечения именно технологической подготовки производства. Это объясняется тем, что автоматизированные системы ТПП специализированы и зависят от характера производства, вида выпускаемой продукции, серийности их выпуска. Кроме того, прикладное программное обеспечение АСТПП неоднородно по назначению, оно формируется из набора продуктов, каждый из которых обеспечивает разработку отдельного вида технологических процессов.

Поэтому возникает необходимость в создании информационного обеспечения в виде универсальной базы данных, с целью снижения трудоемкости и повышения эффективности работ на этапе технологической подготовки производства за счет их использования.

Для технологического процесса сборки обуви клеевого метода крепления авторами создано информационное обеспечение, целью которого является формирование паспорта модели и автоматизированный выбор технологического процесса.

Для создания информационного обеспечения авторами выполнены следующие задачи: 


\begin{tabular}{|c|c|c|c|c|c|c|}
\hline \multirow{4}{*}{ Impact Factor: } & ISRA (India) & $=3.117$ & SIS (USA) & $=0.912$ & ICV (Poland) & $=6.630$ \\
\hline & ISI (Dubai, UAE & $=0.829$ & РИНЦ (Russia & $=0.156$ & PIF (India) & $=1.940$ \\
\hline & GIF (Australia) & $=0.564$ & ESJI (KZ) & $=8.716$ & IBI (India) & $=4.260$ \\
\hline & JIF & $=1.500$ & SJIF (Morocco & $=5.667$ & OAJI (USA) & $=0.350$ \\
\hline
\end{tabular}

выделены критерии, определяющие структуру технологического процесса сборки обуви клеевого метода крепления на основе методов априорного ранжирования и ранговой корреляции;

разработан классификатор и структурная схема кодирования модели обуви для автоматизированного проектирования технологического процесса;

составлена матрица совпадений технологических операций в зависимости от конструкции, материалов и способов обработки заготовок верха, стелечных и подошвенных узлов, каблуков и промежуточных деталей для объективного обоснования порядка составления схемы технологического процесса и алгоритма его выбора;

разработана структурно-логическая модель сборки обуви клеевого метода крепления на основе принципов системного подхода, обеспечивающая выработку оптимальных технологических решений;

разработана информационная поддержка для автоматизированного проектирования технологического процесса сборки обуви в виде совокупности баз данных, которые содержат сведения о различных вариантах выполнения одних и тех же технологических операций в зависимости от оснащенности и мощности предприятия;

построен алгоритм работы программы, в соответствии с которым формируются точные предписания, определяющие вычислительный процесс, ведущий от варьируемых начальных данных к исходному результату;

разработано программное обеспечение, позволяющее формировать технологический процесс сборки обуви клеевого метода крепления с одновременным определением трудоемкости и количества рабочих для производства заданного количества моделей.

Разработанное программное обеспечение соответствует основным показателям качества информационных систем, таких как:

гибкость - способность к адаптации и дальнейшему развитию, возможность приспособления информационной системы к новым условиям, новым потребностям предприятия;

надежность - функционирование без искажения информации, потери данных по «техническим причинам» за счет создания резервных копий хранимой информации, выполнения операций протоколирования, поддержания качества каналов связи и физических носителей информации, использования современных программных и аппаратных средств; эффективность - возможность решать возложенные на нее задачи в минимальные сроки, обеспечивается оптимизацией данных и методов их обработки, применением оригинальных разработок, идей, методов проектирования и подтверждается его способностью минимально зависеть от ресурсов оборудования: процессорного времени, пространства, занимаемого во внутренней и внешней памяти, пропускной способности, используемой в устройствах связи;

безопасность - свойство системы, в силу которого посторонние лица не имеют доступа к информационным ресурсам организации, обеспечивается настройкой параметров запуска таким образом, что пользователь, запустив приложение, видит только главную кнопочную форму и такое меню и панель инструментов, при котором он не может воспользоваться кнопками, предназначенными для разработчика приложения.

Программное обеспечение в соответствии с алгоритмом обрабатывает выбранные условия и выдает на печать готовый вариант техпроцесса на данную модель обуви с расчетом трудоемкости и количества рабочих, а также паспорт модели. При использовании разработанного информационного обеспечения задача технолога по формированию технологического процесса сводится к выбору конструктивных признаков модели и основных ограничений, к которым относятся производственная мощность, наличие оборудования, производственных площадей; анализу результатов; корректировке выбранных условий (в случае необходимости) и выбору оптимального варианта технологического процесса.

Что касается эффективности внедрения информационного обеспечения, любое предприятие может быть оценено с различных сторон, а именно: экономической, финансовой, организационной, временной, экологической, социальной.

Результат расчетов по любому отдельно примененному методу оценки эффективности предложенного решения способен отразить лишь часть их положительных сторон. Между тем, числовые значения возможных к использованию различных критериев могут значительно различаться, а иногда и находиться в конфликте. В такой ситуации оправдано использование синергетической (комплексной) оценки эффективности решений, которые предполагают определение преимуществ не по одному критерию, а по совокупности критериев.

Эффективность от внедрения представленного информационного обеспечения может быть оценена с двух сторон: социальной и экономической. 


\begin{tabular}{|c|c|c|c|c|c|c|}
\hline \multirow{4}{*}{ Impact Factor: } & ISRA (India) & $=3.117$ & SIS (USA) & $=0.912$ & ICV (Poland) & $=6.630$ \\
\hline & ISI (Dubai, UAE & $=0.829$ & РИНЦ (Russia & $=0.156$ & PIF (India) & $=1.940$ \\
\hline & GIF (Australia) & $=0.564$ & ESJI (KZ) & $=8.716$ & IBI (India) & $=4.260$ \\
\hline & JIF & $=1.500$ & SJIF (Morocco & $=5.667$ & OAJI (USA) & $=0.350$ \\
\hline
\end{tabular}

\begin{tabular}{|c|c|c|}
\hline Социальный & эффект & внедрения \\
\hline информационного & обеспечения & для \\
\hline автоматизированного & прое & ктирования \\
\hline технологического & процесса & чается \\
\hline
\end{tabular}

1. В результате внедрения в учебный процесс - повышение уровня подготовки специалистов за счет применения инновационных технологий в образовании.

2. В результате внедрения в производство изменение характера и улучшение условий труда, ресурсная оснащенность трудовой деятельности, повышение профессионализма, увеличение средней продолжительности свободного от «бумажной работы» времени технолога.

Оценка экономической эффективности внедрения информационных технологий зачастую происходит либо на уровне интуиции, либо вообще не производится. С одной стороны, это вызвано нежеланием поставщиков решений тратить значительные усилия на проведение подробного предварительного анализа, с другой стороны, вероятно, присутствует значительная доля недоверия потребителей к получаемым результатам таких исследований. Однако, обе эти проблемы проистекают из одного источника, а именно - отсутствия понятных и надежных методик оценки экономической эффективности ИТ проектов.

Полная экономическая эффективность использования программного обеспечения для автоматизированного проектирования ТПП состоит из экономии в сфере технологической подготовки производства, которая является следствием повышения производительности труда технологов за счет автоматизированного выбора перечня технологических операций с расчетом трудоемкости и количества рабочих.

В сфере производства экономию получают благодаря выбору оптимального технологического процесса вследствие типизации и унификации принимаемых технологических решений. Кроме того, значительно сокращаются сроки подготовки производства, а этот фактор трудно переоценить в наше время, когда конкурентоспособности можно добиться только при часто изменяющемся ассортименте выпускаемой продукции, а для этого необходимо добиться хороших техникоэкономических показателей работы предприятия.

Эти и другие преимущества автоматизированного выбора технологических процессов, хотя многие из них и сложно определить путем прямых экономических расчетов, способствуют существенному улучшению показателей работы обувных предприятий.

Полученные результаты позволяют говорить о достижении синергетического эффекта как с точки зрения технологии (за счет значительного сокращения времени на технологическую подготовку производства, выбора оптимального технологического процесса, сокращения переналадок технологического процесса при смене ассортимента, выбора правильной последовательности запуска образцов), так и с точки зрения эффективности производства в целом, за счет одновременного достижения социального и экономического эффекта.

Сегодня от предприятия легкой промышленности, стремящегося не просто выжить, но и развиваться, требуется умение не просто грамотно эксплуатировать имеющиеся технологии, но в первую очередь, активно позиционировать себя на рынке, поставляя в короткие сроки качественную, удовлетворяющую требованиям, запросы и ожидания потребителей, продукцию по минимальной цене. Иными словами в настоящее время выживет тот, кто быстрее других выпустит на рынок продукцию, наиболее полно соответствующую требованиям потребителей, обеспечив при этом минимальную себестоимость ее производства.

Что должно предпринять предприятие, чтобы перечисленные показатели стали его конкурентными преимуществами?

1. Понимать не только текущие, но и будущие предпочтения клиентов и уметь разрабатывать виды продукции, соответствующие этим предпочтениям.

2. Обеспечить настройку технологических процессов производства, гарантирующую их минимальную себестоимость за счет идентификации и исключения всех видов издержек, не приносящих ценности продукции.

3. Вывести продукцию на рынок быстрее, чем это сделают конкуренты.

Реализация перечисленных задач будет зависеть от того, насколько отлажено и эффективно будут работать на предприятии все подразделения.

Каким образом можно обеспечить эту отлаженную и эффективную работу? С нашей точки зрения,

посредством определения совокупности процессов или видов деятельности, обеспечивающих производство продукции с характеристиками качества, удовлетворяющими требования, запросы и ожидания потребителей регионов ЮФО и СКФО;

установления между процессами четкого и понятного взаимодействия;

определения целей в области качества на уровне предприятия и подразделений, обеспечивающих понимание тех результатов, которые должны быть достигнуты подразделениями, и которые обеспечивают достижение общих целей предприятия; 


\begin{tabular}{|c|c|c|c|c|c|c|}
\hline \multirow{4}{*}{ Impact Factor: } & ISRA (India) & $=3.117$ & SIS (USA) & $=0.912$ & ICV (Poland) & $=6.630$ \\
\hline & ISI (Dubai, UAE & $=0.829$ & РИНЦ (Russia & $=0.156$ & PIF (India) & $=1.940$ \\
\hline & GIF (Australia) & $=0.564$ & ESJI (KZ) & $=8.716$ & IBI (India) & $=4.260$ \\
\hline & JIF & $=1.500$ & SJIF (Morocco & $=5.667$ & OAJI (USA) & $=0.350$ \\
\hline
\end{tabular}

планирования ресурсов, необходимых для достижения целей;

определения процедур, обеспечивающих выполнение работ в подразделениях наиболее эффективным способом;

измерения результатов и сравнения их с поставленными целями;

анализа и принятия решений о том, что следует улучшить в рамках каждого подразделения.

Таким образом, представлена совокупность процессов, за счет функционирования которых формируется система управления предприятием, ориентирующая его на производство продукции, соответствующей по своим характеристикам требованиям, запросам и ожиданиям потребителей и настраивающая все виды деятельности, связанные с обеспечением производства на показатель эффективности, а именно:

выстраивается система идентификации источников издержек, и разработки адекватных мер по их снижению,

формируются достоверные данные, демонстрирующие эффективность использования вложенных инвестиций, что может способствовать привлечению новых инвесторов;

уменьшается себестоимость продукции, что дает возможность снижать цену, расширять рынок и увеличивать объемы производства;

происходит снижение издержек, обычно связаных с сокращением количества брака и других видов отходов, что положительно сказывается на таких показателях работы предприятия, как влияние на окружающую среду, состояние промышленной безопасности;

формируется имидж социальноориентированного предприятия;

выполняется четкая постановка целей и задач перед каждым сотрудником, определяющих результат, который должен быть получен при выполнении работы;

определение ресурсов, необходимых для выполнения работы, и обеспечение ресурсами;

обеспечение знаниями и навыками, необходимыми для понимания того, как следует выполнять работу, чтобы обеспечить ее максимальную эффективность;

измерение результатов работы на уровне сотрудников, подразделений и организации в целом и сравнение результатов с целями;

анализ результатов и адекватное реагирование на них через систему корректирующих и предупреждающих действий.

Как показывает практика, умение реализовать эти процессы на уровне высшего менеджмента создает условия, необходимые для формирования конкурентоспособного предприятия, то есть все это руководитель уже сегодня может взять на вооружение, чтобы обеспечить своим предприятиям эту самую экономическую стабильность.

Кроме того, важно, чтобы наименований продукции было не слишком много. Для большинства российских предприятий основной резерв оптимизации ассортимента до сих пор заложен в значительном сокращении ассортиментного ряда. Слишком большой ассортимент плохо сказывается на экономических показателях - появляется много позиций, которые по объемам продаж не могут выйти даже на уровень безубыточности. В итоге общая рентабельность сильно падает. Только исключение нерентабельных и малорентабельных позиций из ассортимента может дать компании увеличение общей рентабельности на 30-50 \%.

Кроме того, большой ассортимент распыляет силы предприятия, затрудняет грамотное предложение товара клиентам (даже сотрудники отдела продаж не всегда способны объяснить разницу между той или иной позицией или наименованием), рассеивает внимание конечных потребителей.

Здесь будет уместным напомнить о психологии восприятия информации человеком. Реальность такова, что среднестатистический человек способен единовременно воспринять не более 5-7 (реже до 9) смысловых конструктивных решений. Таким образом, человек, делая выбор, сначала выбирает эти самые 5-7 вариантов на основании такого же количества критериев. Если продавец предлагает большее количество критериев выбора, покупатель начинает испытывать дискомфорт и самостоятельно отсеивает незначимые, с его точки зрения, критерии. То же происходит и при выборе собственно товара. Теперь представьте, что происходит, если перед человеком сотня практически не отличимых (для него) товаров, а купить ему нужно один. Люди в такой ситуации ведут себя следующим образом: либо вообще отказываются от покупки, так как не в состоянии сопоставить такое количество вариантов, либо предпочитают то, что уже брали (или что кажется знакомым). Есть и еще одна категории людей (около 7 \%), любители новинок, которые наоборот выберут что-то, что еще опробовано ими.

Таким образом, с точки зрения покупателя (для обеспечения спокойного выбора из поддающихся восприятию вариантов) ассортимент должен состоять не более чем из 5-7 групп по 5-7 наименованиям, т.е. весь ассортимент с точки зрения восприятия оптимально должен состоять из 25-50 наименований. Если наименований объективно больше, то выход состоит только в дополнительной классификации. 


\begin{tabular}{|c|c|c|c|c|c|c|}
\hline \multirow{4}{*}{ Impact Factor: } & ISRA (India) & $=3.117$ & SIS (USA) & $=0.912$ & ICV (Poland) & $=6.630$ \\
\hline & ISI (Dubai, UAE & $=0.829$ & РИНЦ (Russia & $=0.156$ & PIF (India) & $=1.940$ \\
\hline & GIF (Australia) & $=0.564$ & ESJI (KZ) & $=8.716$ & IBI (India) & $=4.260$ \\
\hline & JIF & $=1.500$ & SJIF (Morocco & $=5.667$ & OAJI (USA) & $=0.350$ \\
\hline
\end{tabular}

Считается общепринятым, что покупателю нужен широкий ассортимент. Этот самый широкий ассортимент часто обозначают даже как конкурентное преимущество. Но на деле получается, что для производителя широкий ассортимент - это сотни наименований продукции, а для потребителя - 7 наименований уже более чем достаточно. Таким образом потребителю нужен вовсе не широкий ассортимент, а необходимое для него разнообразие.

Это возможно, если будут реализованы составные части стратегии развития России до 2025 года, а именно: будет решена задача по переводу экономического развития России от инерционного энергетического сценария к альтернативному инновационному социально ориентированному типу развития, при формировании эффективной промышленной политики, для чего необходимо:

- разработать и законодательно закрепить основы эффективной государственной промышленной политики как системы согласованных целей, приоритетов и действий государственных органов, бизнеса и науки по повышению эффективности работы промышленности, обеспечению высокой конкурентоспособности продукции, товаров и услуг и неуклонного роста производства. При её формировании предусмотреть опережающий рост во всех отраслях высокотехнологичной продукции c увеличением её доли в общем объеме промышленного производства к 2025 году не менее $50 \%$, равенство субъектов промышленной политики, гарантии прав собственности;

- обеспечить реализацию особых мер поддержки приоритетных высокотехнологичных отраслей, чтобы создать условия для эффективного развития всей промышленности России;

Обеспечить увеличение объема инвестиций, создание экономических и правовых предпосылок для внедрения и использования высоких технологий и новых материалов, в первую очередь разрабатываемых в России, для этого следует:

- законодательно закрепить основы национальной инновационной системы в Российской Федерации; установить повышающий коэффициент на расходы на НИОКР, включаемые в себестоимость; снизить НДС до $12 \%$; освободить от налогообложения прибыль предприятий, инвестируемую в производство; создать институты долгосрочного кредитования модернизации и технического перевооружения промышленности под невысокий процент; усовершенствовать систему администрирования НДС, изменить порядок и сроки уплаты налогов для пополнения предприятиями промышленности собственных оборотных средств; осуществить переход на дифференцированную ставку налога на добычу полезных ископаемых в зависимости от природных условий, степени выработанности месторождений и т.д.;

- разработать и осуществить меры по борьбе с ценовым монополизмом, по стабилизации тарифов на услуги естественных монополий, подготовить и принять федеральный закон «О ценовой и тарифной политике»; содействовать созданию и продвижению отечественных национальных, региональных и корпоративных брендов отечественной продукции для развития конкурентоспособной среды с целью создания конкурентной продукции, для чего внедрить систему качества, содействовать реализации программ, направленных на выявление, независимую оценку качества и продвижение отечественной продукции, активизировать работы по стандартизации, включая затраты на научные исследования в этой сфере по разработке новых и корректировке существующих национальных стандартов;

- учитывать, что машиностроение является системообразующим комплексом, для чего обеспечить в сжатые сроки его модернизацию и восстановление технологической основы национального машиностроительного комплекса - станкостроения. В этих целях использовать как отечественные разработки, так и закупку зарубежной техники и технологий, используя международное разделение труда, шире задействовать механизм лизинга. Кроме общих мер поддержки промышленности, необходимо дополнительно подготовить и принять государственную стратегию развития станкоинструментальной промышленности на период до 2020 года, включая реализацию специальных целевых программ, направленных на финансирование перспективных научных разработок;

- модифицировать размеры и порядок взимания таможенных сборов для стимулирования импорта новейшего технологического оборудования при одновременном содействии возрождению отечественного производства такого оборудования, в частности, отменить таможенные пошлины и НДС на ввоз нового импортного технологического оборудования, не производимого в стране;

- разработать и принять комплекс специальных мер по обеспечению машиностроения и станкостроения научными и инженерными кадрами, высококвалифицированными рабочими, особенно в сфере научных исследований и прикладных разработок, сформировать систему трудоустройства молодых специалистов; разработать и принять поправки в Налоговый 


\begin{tabular}{|c|c|c|c|c|c|c|}
\hline \multirow{4}{*}{ Impact Factor: } & ISRA (India) & $=3.117$ & SIS (USA) & $=0.912$ & ICV (Poland) & $=6.630$ \\
\hline & ISI (Dubai, UAE & $=0.829$ & РИНЦ (Russia & $=0.156$ & PIF (India) & $=1.940$ \\
\hline & GIF (Australia) & $=0.564$ & ESJI (KZ) & $=8.716$ & IBI (India) & $=4.260$ \\
\hline & JIF & $=1.500$ & SJIF (Morocco & $=5.667$ & OAJI (USA) & $=0.350$ \\
\hline
\end{tabular}

кодекс (гл. 25), устанавливающие режимы ускоренной амортизации и преференций (премий), позволяющих амортизировать активную часть основных фондов в объеме, превышающем их балансовую стоимость;

- принять меры по стимулированию системы государственного и коммерческого лизинга технологического оборудования в целях технического перевооружения отраслей машиностроения; рассмотреть возможность предварительной 100-процентной оплаты из средств федерального бюджета стоимости поставок предприятиям уникального импортного оборудования, в т. числе на лизинговой основе, необходимого для целей технического перевооружения станкостроения; машиностроения

и

- ввести в практику проведение систематической всероссийской переписи металлообрабатывающего оборудования, что позволит иметь объективные данные о состоянии станочного парка машиностроительных предприятий;

- разработать и реализовать комплекс мер по решению проблемы недостатка квалифицированных кадров в промышленности, по повышению качества подготовки кадров в высших учебных заведениях, по обеспечению молодых специалистов жильем на льготных условиях, ввести в практику подготовку специалистов по государственному заказу, на основе частно-государственного партнёрства обеспечить современной техникой и общежитиям профессионально-технические училища, разрешить предприятиям средства, израсходованные на подготовку кадров относить на затраты производства в полном объёме, принять специальные законодательные и нормативные документы, направленные на обеспечение промышленное освоение Сибири и Дальнего Востока;

- разработать и законодательно закрепить комплекс мер, обеспечивающий заинтересованность хозяйствующих субъектов в активном участии в проектах повышения ресурсо- и энергоэффективности, включая элементы денежно-кредитной политики, валютного и инвестиционного регулирования, механизмы субсидирования, специальные налоговые и амортизационные режимы;

- реализовать комплекс мер, направленных на массовое развитие малых и средних предприятий в промышленно-производственной, инновационной сферах и в сфере услуг, в первую очередь, в части обеспечения малым и средним предприятиям доступа к производственным помещениям, закупки оборудования, в т. числе на лизинговой основе, развития микрофинансирования и кредитной кооперации;
- принять меры для создания российской перерабатывающей промышленности равных конкурентных условий с импортерами, ускорить разработку и принятие федерального закона «О торговле» и сопутствующих нормативных актов по организации эффективного функционирования российской оптовой и розничной торговли;

- разработать стратегию регионального промышленного развития субъектов РФ, в том числе территориального размещения производительных сил на долгосрочную перспективу, увязать развитие региональной инфраструктуры с размещением промышленных объектов;

- четко прописать систему реализации основополагающих целей государственной промышленной политики, обеспечивающих решение системных проблем реального сектора экономики, соотнести потребность в инвестициях, источники инвестиций и реально достижимые социально-экономические результаты.

В Стратегии развития легкой промышленности на период до 2020 года и плана мероприятий по еe реализации учтены национальные интересы России (повышение уровня и качества жизни населения, здоровья нации, стратегической и экономической безопасности государства), предложения субъектов Российской Федерации, общественных организаций и объединений о необходимых мерах поддержки отрасли по приоритетным направлениям ее развития.

В основу Стратегии был заложен переход легкой промышленности на инновационную модель развития. Особое внимание уделено вопросам защиты внутреннего рынка от теневого товарооборота, технического перевооружения и модернизации производства, импортозамещения и экспорта.

Сегодня легкая промышленность Российской Федерации - это важнейший многопрофильный и инновационнопривлекательный сектор экономики.

Вклад легкой промышленности в промышленное производство России сегодня составляет порядка 1 \% (в 1991 г. этот показатель был равен $11,9 \%$ и соответствовал уровню развитых стран, таких как США Германия и Италия, которые на протяжении всех этих лет сохраняют этот показатель на уровне $8-12 \%$ ), в объеме экспорта $-1,3 \%$.

В настоящее время в легкой промышленности функционирует 14 тыс. крупных, средних и малых предприятий, расположенных в 72 регионах страны. Около 70 \% предприятий являются градообразующими. Среднесписочная численность промышленнопроизводственного персонала, занятого в 


\begin{tabular}{|c|c|c|c|c|c|c|}
\hline \multirow{4}{*}{ Impact Factor: } & ISRA (India) & $=3.117$ & SIS (USA) & $=0.912$ & ICV (Poland) & $=6.630$ \\
\hline & ISI (Dubai, UAE & $=0.829$ & РИНЦ (Russia & $=0.156$ & PIF (India) & $=1.940$ \\
\hline & GIF (Australia) & $=0.564$ & ESJI (KZ) & $=8.716$ & IBI (India) & $=4.260$ \\
\hline & JIF & $=1.500$ & SJIF (Morocco & $=5.667$ & OAJI (USA) & $=0.350$ \\
\hline
\end{tabular}

отрасли, 462,8 тыс. человек, $75 \%$ которого составляют женщины. Научное обеспечение отрасли осуществляют 15 учебных, научно исследовательских и проектных институтов, многие разработки которых соответствуют и даже превышают мировой уровень.

Основными территориями размещения предприятий, определяющих промышленную и экономическую политику отрасли, являются Центральный (55 предприятий), Приволжский (30) и Южный (17) федеральные округа, которые имеют наибольший удельный вес в общем объеме производимой продукции и являются наиболее социально значимыми.

Результаты работы отрасли за 2017 г. показали, что она в условиях кризиса в состоянии нарастить объёмы производства в подотраслях, ориентированных непосредственно на рынок. Следует отметить, что в условиях кризиса резко сужается ассортимент поставляемых в Россию товаров. Это дает отечественной легкой промышленности стратегические возможности для занятия освобождающихся ниш и упрочения своих позиций на рынке.

В 2018 г. оборот розничной торговли продукцией легкой промышленности составил 2,0 трилн. руб., его доля в розничном товарообороте страны $14,5 \%$, а в розничном товарообороте непродовольственных товаров $26,3 \%$. По уровню потребления продукция легкой промышленности уступает только продовольственным товарам, намного опережая рынки бытовой электроники, легковых автомобилей и других товаров. С учетом макроэкономических показателей и тенденций развития рынок товаров легкой промышленности к 2025 г. может составить свыше 3,3 трилн. руб.

Существующие преференции и решаемые в той или иной степени проблемы на федеральном и региональном уровнях пока недостаточны, чтобы устранить влияние негативных факторов на развитие отрасли и превратить ее в конкурентоспособный и саморазвивающийся сектор экономики, а отечественным производителям укрепить свои позиции на внутреннем рынке и на равных конкурировать на мировом рынке не только с производителями Китая, Турции, Индии и ряда других развивающихся стран, но и со странами ЕС и США.

Ситуацию в отрасли еще более усугубил мировой финансовый кризис. В условиях кризиса даже те предприятия, которые за последние годы добились положительных результатов в инновационном развитии, уделяя значительное внимание модернизации производства, уже вынуждены и будут вынуждены в ближайшие годы сокращать объемы производства и отказываться от долгосрочных вложений. Это обусловлено возникшими трудностями, связанными с привлечением банковских кредитов (доля заемных средств в оборотных средствах за последние годы достигла 40 \%), с одной стороны, увеличением объемов официального импорта, контрафактной и контрабандной продукции, падением спроса и замедлением реализации многих видов товаров потребительского и производственно-технического назначения, сокращением рабочих и специалистов - с другой стороны.

Отсутствие кардинальных мер по решению выявленных проблем существенно скажется на экономике отрасли, ее технологическое отставание в обозримой перспективе может стать необратимым процессом, что приведет к деградации наукоемких производств, к усилению товарной зависимости от зарубежных стран, потери государства будут геометрически расти, что повысит стратегическую и национальную опасность России.

Изменить сложившуюся ситуацию можно, только разработав и реализовав антикризисные меры и мероприятия, направленные на подъем экономики легкой промышленности, придание ей новых импульсов в инновационном, социальном и региональном развитии, в повышении конкурентоспособности и эффективности производства на новом технико-технологическом уровне. Сегодня отрасль обеспечивает своей продукцией только четверть платежеспособного спроса населения, а мобилизационные потребности страны - всего лишь на 17-36\%, что противоречит закону о безопасности государства, согласно которому в объеме продукции стратегического назначения доля отечественной должна составлять не менее $51 \%$. Поэтому сегодня перед легкой промышленностью стоят новые вызовы и задачи, решение которых требует новых подходов не только на краткосрочную, но и на долгосрочную перспективу.

Это обусловило цель Стратегии создание условий для ускоренного инновационного развития легкой промышленности России, обеспечения эффективного соответствия объемов производства, качества и ассортимента продукции совокупному спросу потребителей, повышения национальной значимости отрасли и ее имиджа в мировом сообществе.

Цели и задачи Стратегии соответствуют проводимой политике государства в области инновационного и социально-экономического развития России в среднесрочной и долгосрочной перспективе. Стратегия призвана стать: одним из основных инструментов в решении проблем отрасли и взаимоувязать задачу её экономического роста с обеспечением потребностей граждан страны, силовых структур 


\begin{tabular}{|c|c|c|c|c|c|c|}
\hline \multirow{4}{*}{ Impact Factor: } & ISRA (India) & $=3.117$ & SIS (USA) & $=0.912$ & ICV (Poland) & $=6.630$ \\
\hline & ISI (Dubai, UAE & $=0.829$ & РИНЦ (Russia & $=0.156$ & PIF (India) & $=1.940$ \\
\hline & GIF (Australia) & $=0.564$ & ESJI (KZ) & $=8.716$ & IBI (India) & $=4.260$ \\
\hline & JIF & $=1.500$ & SJIF (Morocco & $=5.667$ & OAJI (USA) & $=0.350$ \\
\hline
\end{tabular}

и смежных отраслей в качественных и доступных потребительских товарах, в продукции технического и стратегического назначения.

Реализация Стратегии даст возможность легкой промышленности России стать индустриально развитой отраслью, которая будет обеспечивать работой многие тысячи людей, повышать благосостояние работающих, укреплять стратегическую и экономическую безопасность страны.

Главный результат Стратегии - это переход легкой промышленности на качественно новую модель инновационного, экономического и социального развития, основа которой - новая технологическая и научная база, новые методы управления производством, взаимосвязь науки, производства и бизнеса. Это обеспечение эффективного соответствия объемов производства, качества и ассортимента продукции совокупному спросу российского и мирового рынков.

Ещё раз хотелось бы заострить внимание, что всё это станет реальностью, если будет реализовано одно главное условие, а именно, продукция лёгкой промышленности будет производиться высокого качества и с учетом интересов этого самого потребителя.

\section{References:}

1. Prokhorov, V. T., et al. (2008). Quality management of competitive and in-demand materials and products. Monograph. under the General editorship of doctor of technical Sciences, Professor V. T. Prokhorov. (Eds.). (p.654). Mine: Publishing house GOU VPO yurgues.

2. Prokhorov, V. T., et al. (2012). Managing production of competitive products in demand. under the General editorship of doctor of technical Sciences, Professor V. T. Prokhorov (Eds.). VPO yurgues. (p.280). Novocherkassk: yurgtu (NPI).

3. Prokhorov, V. T., et al. (2018). The competitiveness of enterprise and product competitiveness is the key to successful import substitution of goods demanded by consumers in the regions of SFD and NCFD. collective monograph / under the General editorship of Dr. sci. prof. V. T. Prokhorova (Eds). Institute of service sector and entrepreneurship (branch) of the don state technical University. (p.337). Novocherkassk: Lik.

4. (1975). Hegel encyclopedia of philosophical Sciences. Vol.1. Science of logic: translation with it. (p.452). Moscow: Thought.

5. Sitkowski, E. P. (n.d.). encyclopedia of philosophy Hegel. Preface to 1 T. (pp.5-50). Hegel: Science of logic.

6. Ricardo, D. (1955). SOC. in 3 t, T II. Moscow: GOS. Izd-vo polit. lit-ry. M., 1955. Ricardo's Preface to the first edition. From 30-31, CH. $\mathrm{XXX}$ " on the impact of supply and demand on prices." pp. 314-317.

7. Adler, Y. P., Aronov, I. Z., \& Shper, V. L. (1999). What is the coming century preparing for us? (management of the XXI century-a brief overview of the main trends). Reliability and quality control, № 1 .

8. (2000). Anthology of Russian quality. (p.378). Moscow: Standards and quality.

9. Deming, W. E. (1994). out of the crisis: pens. with English. (p.415). Tver: Alba.

10. Ford, G. (1989). My life, my achievements: TRANS. with English. Moscow: Finance and statistics, (reprint edition 1924).

11. Schonberger, R. (1988). Japanese methods of production management. Nine simple lessons: socr. Per. with English. (p.211). Moscow: Economy.

12. Aleshin, L. N., Alexandrovskaya, V. I., \& Kruglov, S. (2004). Philosophical and social aspects of quality. (p.438). Moscow: Logos.

13. (2015). GOST R ISO 9001-2015 quality management System. The requirements of GOST R ISO 9001-2015 National standard russian federation state quality management. date of implementation 2015 - 11-01.

14. (2016). GOST R 57189-2016 / ISO / TS 9002:2016. National standard of the Russian Federation. Quality management system. Guidance on the application of ISO 9001:2015 (ISO/TS 9002:2016, IDT)" (app. By the order of Rosstandart on 25.10.2016 N 1499-St). [Official website of the International organization for standardization (ISO)] Retrieved May 22, 2018, from http://www.iso.org/iso/ru/catalogue detail?csnu $\underline{\text { mber }=52844}$

15. (2010). GOST R ISO 9004-2010. Managing for the sustained success of an organization. Quality management approach.

16. (2009). GOST R ISO/TU 16949-2009. Quality management system. Special requirements for the application of ISO 9001: 2008 in the 


\begin{tabular}{|c|c|c|c|c|c|c|}
\hline \multirow{4}{*}{ Impact Factor: } & ISRA (India) & $=3.117$ & SIS (USA) & $=0.912$ & ICV (Poland) & $=6.630$ \\
\hline & ISI (Dubai, UAE & $=0.829$ & РИНЦ (Russia & $=0.156$ & PIF (India) & $=1.940$ \\
\hline & GIF (Australia) & $=0.564$ & ESJI (KZ) & $=8.716$ & IBI (India) & $=4.260$ \\
\hline & JIF & $=1.500$ & SJIF (Morocce & $=5.667$ & OAJI (USA) & $=0.350$ \\
\hline
\end{tabular}

automotive industry and organizations producing the relevant spare parts.

17. Mishin, Y., et al. (2008). Quality management of competitive and in-demand materials and products. monograph / under the General editorship of doctor of technical Sciences, Professor V. T. Prokhorov (Eds.). (p.654). Mines Publishing house GOU VPO yurgues.

18. Mishin, Y., et al. (2009). How to ensure a steady demand for domestic products of the fashion industry. monograph. (p.443). Mine: publishing house of urgues.

19. Prokhorov, V. T., et al. (2009). Technical regulation: the basic basis of the quality of materials, products and services: monograph. (p.325). Novocherkassk: The Face.

20. (n.d.). ISCIENCE.IN.UA "Actual research in the modern world" Issue 8 (40) part 1 ISSN 2524-0986, 63.

21. Prokhorov, V. T., et al. (2012). Managing production of competitive products in demand. under the General editorship of doctor of technical Sciences, Professor V. T. Prokhorov (Eds.). (p.280). Novocherkassk: yurgtu (NPI).

22. Balandyuk, N. M., et al. (2012). The restructuring of enterprises as one of the most effective forms of improving the competitiveness of enterprises on markets with unstable demand: monograph. under the General editorship of doctor of technical Sciences, Professor V. T. Prokhorov (Eds). FGBOU VPO "South-ROS. state University of Economics and service". (p.347). Mines: FGBOU VPO yurgues.
23. Prokhorov, T. V., Aspen, T. M., \& Walnut, L. G. (2012). Innovative technologies in the industry thanks to the production of competitive and popular products. monograph / under the General editorship of doctor of technical Sciences, Professor V. T. Prokhorov (Eds.). VoIP (branch) of DSTU. (p.435). Mines: Isoip (branch) DSTU.

24. Chernovoy, I. V., Kolesnikov, S. A., \& Tashpulatov, S. S. (2015). Science-intensive technologies in the service of human ecology [monograph]. Under the General editorial prof. Chernovoy I. V. (Eds.). materials of II International scientific-technical conference "high technologies in the service of human ecology, VoIP (branch) of DSTU in Shakhty. (p.144). Novocherkassk: Lik.

25. (2016). About technical regulation: Feder. law No. 184: [adopted by the State. Duma 15 December 2002: approval. Federation Council December 18, 2002 (as amended on April 5, 2016) (version effective from July 1, 2016)]. (p.36). Moscow.

26. (2012). About the approval of criteria of accreditation of certification bodies and testing laboratories (centers) and requirements to them: the Order of the Ministry of economic development of Russia of 16.10.2012 No. 682. Ed. - The Ministry of justice of Russia on November 16, 2012.

27. (2014). GOST R ISO/IEC 17000-2012. Conformity assessment. Dictionary and General principles. - Enter. 2013-09-01. (p.19). FSUE STANDARTINFORM. 